\title{
Trends in Taxonomy of Chagas Disease Vectors (Hemiptera, Reduviidae, Triatominae): From Linnaean to Integrative Taxonomy
}

\author{
Kaio Cesar Chaboli Alevi ${ }^{1,2,3}{ }^{\mathbb{D}}$, Jader de Oliveira ${ }^{1,2} \mathbb{D}$, Dayse da Silva Rocha ${ }^{3}$ and Cleber Galvão ${ }^{3, *(\mathbb{D})}$ \\ 1 Laboratório de Parasitologia, Faculdade de Ciências Farmacêuticas, Universidade Estadual Paulista “Júlio de \\ Mesquita Filho" (UNESP), Rodovia Araraquara-Jaú km 1, Araraquara 14801-902, Brazil; \\ kaiochaboli@hotmail.com (K.C.C.A.); jdr.oliveira@hotmail.com (J.d.O.) \\ 2 Laboratório de Entomologia em Saúde Pública, Faculdade de Saúde Pública, Universidade de São \\ Paulo (USP), Av. Dr. Arnaldo 715, São Paulo 01246-904, Brazil \\ 3 Laboratório Nacional e Internacional de Referência em Taxonomia de Triatomíneos, Instituto Oswaldo \\ Cruz (FIOCRUZ), Av. Brasil 4365, Pavilhão Rocha Lima, Sala 505, Rio de Janeiro 21040-360, Brazil; \\ dayseroch@gmail.com \\ * Correspondence: clebergalvao@gmail.com
}

Citation: Alevi, K.C.C.; de Oliveira, J.; da Silva Rocha, D.; Galvão, C. Trends in Taxonomy of Chagas Disease Vectors (Hemiptera, Reduviidae, Triatominae): From Linnaean to Integrative Taxonomy. Pathogens 2021, 10, 1627. https:// doi.org/10.3390/pathogens10121627

Academic Editors: Lawrence

S. Young, Rubén Bueno-Marí,

Daniel Bravo-Barriga and

Rodrigo Morchón

Received: 30 October 2021

Accepted: 10 December 2021

Published: 15 December 202

Publisher's Note: MDPI stays neutral with regard to jurisdictional claims in published maps and institutional affiliations.

Copyright: (C) 2021 by the authors. Licensee MDPI, Basel, Switzerland. This article is an open access article distributed under the terms and conditions of the Creative Commons Attribution (CC BY) license (https:// creativecommons.org/licenses/by/ $4.0 /)$.

\begin{abstract}
Chagas disease is a neglected tropical disease caused by the protozoan Trypanosoma cruzi and transmitted mainly by members of the subfamily Triatominae. There are currently 157 species, grouped into 18 genera and five tribes. Most descriptions of triatomine species are based on classical taxonomy. Facing evolutionary (cryptic speciation and phenotypic plasticity) and taxonomic (more than 190 synonymizations) problems, it is evident that integrative taxonomy studies are an important and necessary trend for this group of vectors. Almost two-and-a-half centuries after the description of the first species, we present for the first time the state-of-the-art taxonomy of the whole subfamily, covering from the initial classic studies to the use of integrative taxonomy.
\end{abstract}

Keywords: Triatominae; classical taxonomy; molecular taxonomy; integrative taxonomy

\section{Triatominae: The Vectors of Chagas Disease}

Chagas disease is a neglected tropical disease caused by the protozoan Trypanosoma cruzi (Chagas, 1909) (Kinetoplastida, Trypanosomatidae) [1]. This disease is found mainly in 21 Latin American countries, where it is mostly vector-borne, more specifically by members of the subfamily Triatominae (Hemiptera, Reduviidae) [1]. Triatomines or kissing bugs are hematophagous insects that have a habit of defecating during or after the blood meal-if they are infected with T. cruzi, they release the parasite in the feces/urine [1]. An estimated 8 million people are infected worldwide, and more than 65 million people at risk of acquiring the disease, which causes more than 12,000 deaths per year, the vector control being the most useful method to prevent new infections [1,2].

There are currently 157 species (154 extant species and three fossils), grouped into 18 genera and five tribes (Table 1) [3-7], being all potential vectors of T. cruzi. Taxonomic studies of Triatominae started in the 18th century with the description of Triatoma rubrofasciata (De Geer, 1773) (as Cimex rubro-fasciatus) [8]. Almost two and a half centuries after the description of the first species, we presented for-the first time- - a review of the state-of-the-art of taxonomy of the whole subfamily, covering from the initial classic studies to the use of integrative taxonomy, a term formally introduced only in 2005 to describe taxa by integrating information from different data and methodologies $[9,10]$. 
Table 1. Tribes, genera, and number of species that make up the subfamily Triatominae.

\begin{tabular}{ccc}
\hline Tribe & Genus & Species (n) \\
\hline Alberproseniini & Alberprosenia & 2 \\
\hline Bolboderini & Belminus & 9 \\
& Bolbodera & 1 \\
& Microtriatoma & 2 \\
& Parabelminus & 2 \\
\hline Cavernicolini & Cavernicola & 2 \\
\hline Rhodniini & Psammolestes & 3 \\
& Rhodnius & 21 \\
\hline Triatomini & Dipetalogaster & 1 \\
& Eratyrus & 2 \\
& Hermanlentia & 1 \\
& Linshcosteus & 6 \\
& Mepraia & 3 \\
& Nesotriatoma & 3 \\
& Panstrongylus & 15 \\
& Paratriatoma & 2 \\
& Triatoma & 81 \\
\hline Total & Paleotriatoma & 1 \\
\hline
\end{tabular}

\section{Applications and Limitations of Triatominae Taxonomic Studies}

For 225 years (1773-1998), the descriptions of triatomine species have been based only on studies of classical taxonomy (using descriptive morphology, comparative morphology, and/or morphometry) (Table 2). Although these analyses are imperative and are present in the description of all species of the subfamily Triatominae (Table 2), in the last decade, other approaches (such as biochemical [5,11], cytogenetic [5,12], phylogenetic [5,13-17] and/or of reproductive barriers [5]) started to be combined with the characterization of morphology and/or morphometry, employing the integrative taxonomy in the study of these insect vectors (Table 2).

More than 190 synonymization acts occurred in the subfamily Triatominae [18,19], with the majority of synonymized taxa being described from classical taxonomy. The use of combined analyses for the characterization of a taxon greatly reduces the chances of synonymization (although it does not make it impossible $[19,20]$ ). Based on the synonymization events and the importance of multi-analyses for the characterization of a taxon, we will discuss the current issues, applications, and limitations of classical, molecular, and integrative taxonomy. 
Table 2. Species, taxonomic tools, and taxonomic classification used in the description of Triatominae taxa.

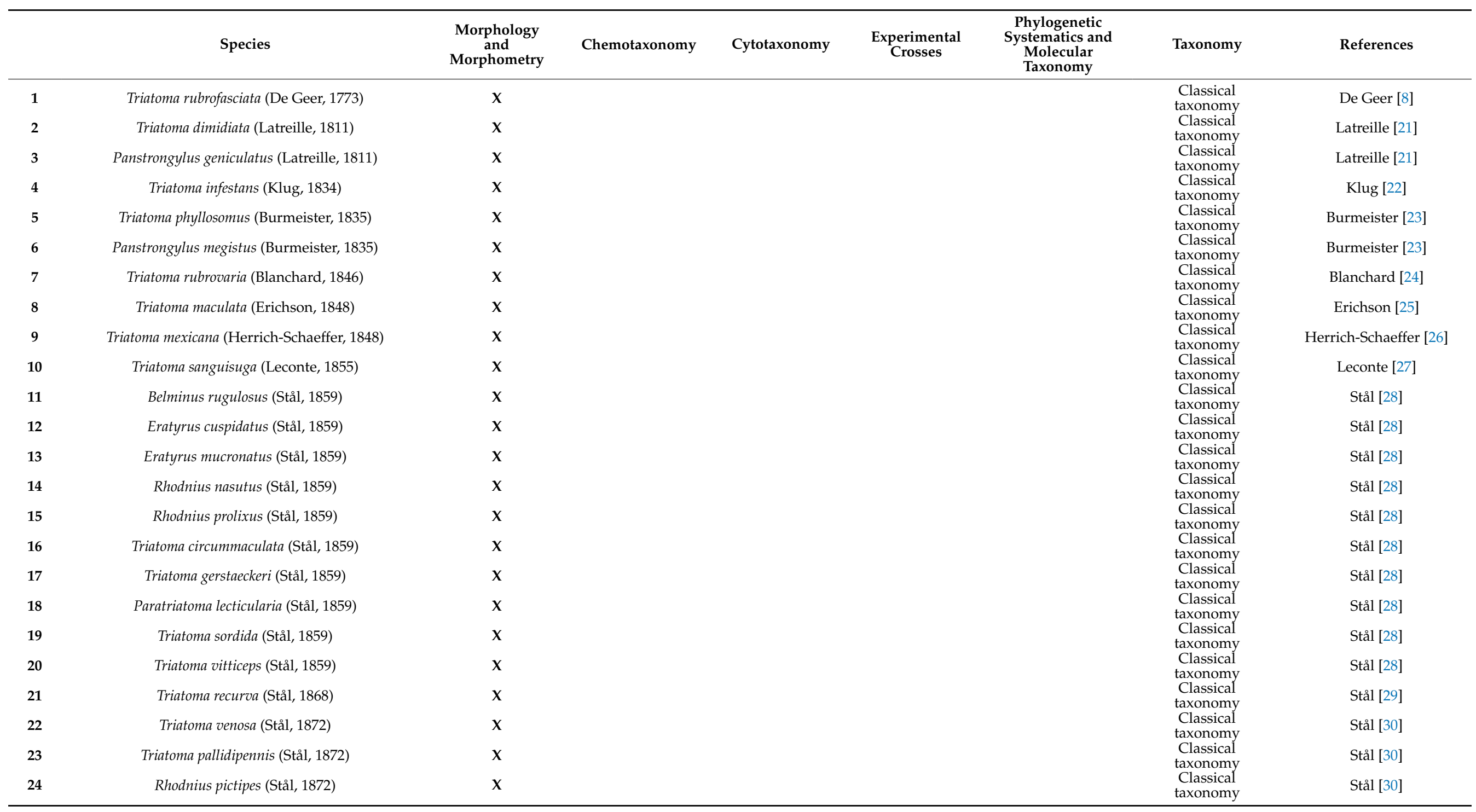


Table 2. Cont.

\begin{tabular}{|c|c|c|c|c|c|c|c|c|}
\hline & Species & $\begin{array}{c}\text { Morphology } \\
\text { and } \\
\text { Morphometry }\end{array}$ & Chemotaxonomy & Cytotaxonomy & $\begin{array}{l}\text { Experimental } \\
\text { Crosses }\end{array}$ & $\begin{array}{l}\text { Phylogenetic } \\
\text { Systematics and } \\
\text { Molecular } \\
\text { Taxonomy }\end{array}$ & Taxonomy & References \\
\hline 25 & Triatoma nigromaculata (Stål, 1872) & $x$ & & & & & $\begin{array}{l}\text { Classical } \\
\text { taxonomy }\end{array}$ & Stål [30] \\
\hline 26 & Panstrongylus lignarius (Walker, 1873) & $x$ & & & & & $\begin{array}{l}\text { Classical } \\
\text { taxonomy }\end{array}$ & Walker [31] \\
\hline 27 & Panstrongylus guentheri (Berg, 1879) & $\mathrm{x}$ & & & & & $\begin{array}{l}\text { Classical } \\
\text { taxonomy }\end{array}$ & Berg [32] \\
\hline 28 & Triatoma rubida (Uhler, 1894) & $x$ & & & & & $\begin{array}{l}\text { Classical } \\
\text { taxonomy }\end{array}$ & Uhler [33] \\
\hline 30 & Triatoma protracta (Uhler, 1894) & $x$ & & & & & $\begin{array}{l}\text { Classical } \\
\text { taxonomy }\end{array}$ & Uhler [33] \\
\hline 31 & Panstrongylus rufotuberculatus (Champion, 1899) & $x$ & & & & & $\begin{array}{l}\text { Classical } \\
\text { taxonomy }\end{array}$ & Champion [34] \\
\hline 32 & Triatoma migrans (Breddin, 1903) & $x$ & & & & & $\begin{array}{l}\text { Classical } \\
\text { taxonomy }\end{array}$ & Breddin [35] \\
\hline 33 & Linshcosteus carnifex (Distant, 1904) & $X$ & & & & & $\begin{array}{l}\text { Classical } \\
\text { taxonomy }\end{array}$ & Distant [36] \\
\hline 34 & Bolbodera scabrosa (Valdés, 1910) & $x$ & & & & & $\begin{array}{l}\text { Classical } \\
\text { taxonomy }\end{array}$ & Valdés [37] \\
\hline 35 & Nesotriatoma flavida (Neiva, 1911) & $x$ & & & & & $\begin{array}{l}\text { Classical } \\
\text { taxonomy }\end{array}$ & Neiva [38] \\
\hline 37 & Panstrongylus howardi (Neiva, 1911) & $x$ & & & & & $\begin{array}{l}\text { Classical } \\
\text { taxonomy }\end{array}$ & Neiva [40] \\
\hline 38 & Triatoma brasiliensis (Neiva, 1911) & $x$ & & & & & $\begin{array}{l}\text { Classical } \\
\text { taxonomy }\end{array}$ & Neiva [41] \\
\hline 39 & Triatoma neotomae (Neiva, 1911) & $x$ & & & & & $\begin{array}{l}\text { Classical } \\
\text { taxonomy }\end{array}$ & Neiva [42] \\
\hline 40 & Triatoma indictiva (Neiva, 1912) & $\mathrm{x}$ & & & & & $\begin{array}{l}\text { Classical } \\
\text { taxonomy }\end{array}$ & Neiva [43] \\
\hline 41 & Triatoma platensis (Neiva, 1913) & $x$ & & & & & $\begin{array}{l}\text { Classical } \\
\text { taxonomy }\end{array}$ & Neiva [44] \\
\hline 42 & Rhodnius brethesi (Matta, 1919) & $\mathrm{x}$ & & & & & $\begin{array}{l}\text { Classical } \\
\text { taxonomy }\end{array}$ & Matta [45] \\
\hline 43 & Panstrongylus lutzi (Neiva \& Pinto, 1923) & $x$ & & & & & $\begin{array}{l}\text { Classical } \\
\text { taxonomy }\end{array}$ & Neiva and Pinto [46] \\
\hline 44 & Rhodnius domesticus (Neiva \& Pinto, 1923) & $\mathrm{x}$ & & & & & $\begin{array}{l}\text { Classical } \\
\text { taxonomy }\end{array}$ & Neiva and Pinto [47] \\
\hline 45 & Triatoma melanocephala (Neiva \& Pinto, 1923) & $\mathrm{x}$ & & & & & $\begin{array}{l}\text { Classical } \\
\text { taxonomy }\end{array}$ & Neiva and Pinto [48] \\
\hline 46 & Triatoma bouvieri (Larrousse, 1924) & $x$ & & & & & $\begin{array}{l}\text { Classical } \\
\text { taxonomy }\end{array}$ & Larrousse [49] \\
\hline 47 & Triatoma petrocchiae (Pinto \& Barreto, 1925) & $x$ & & & & & $\begin{array}{l}\text { Classical } \\
\text { taxonomy }\end{array}$ & Pinto and Barreto [50] \\
\hline 48 & Psammolestes arthuri (Pinto, 1926) & $x$ & & & & & $\begin{array}{l}\text { Classical } \\
\text { taxonomy }\end{array}$ & Pinto [51] \\
\hline
\end{tabular}


Table 2. Cont.

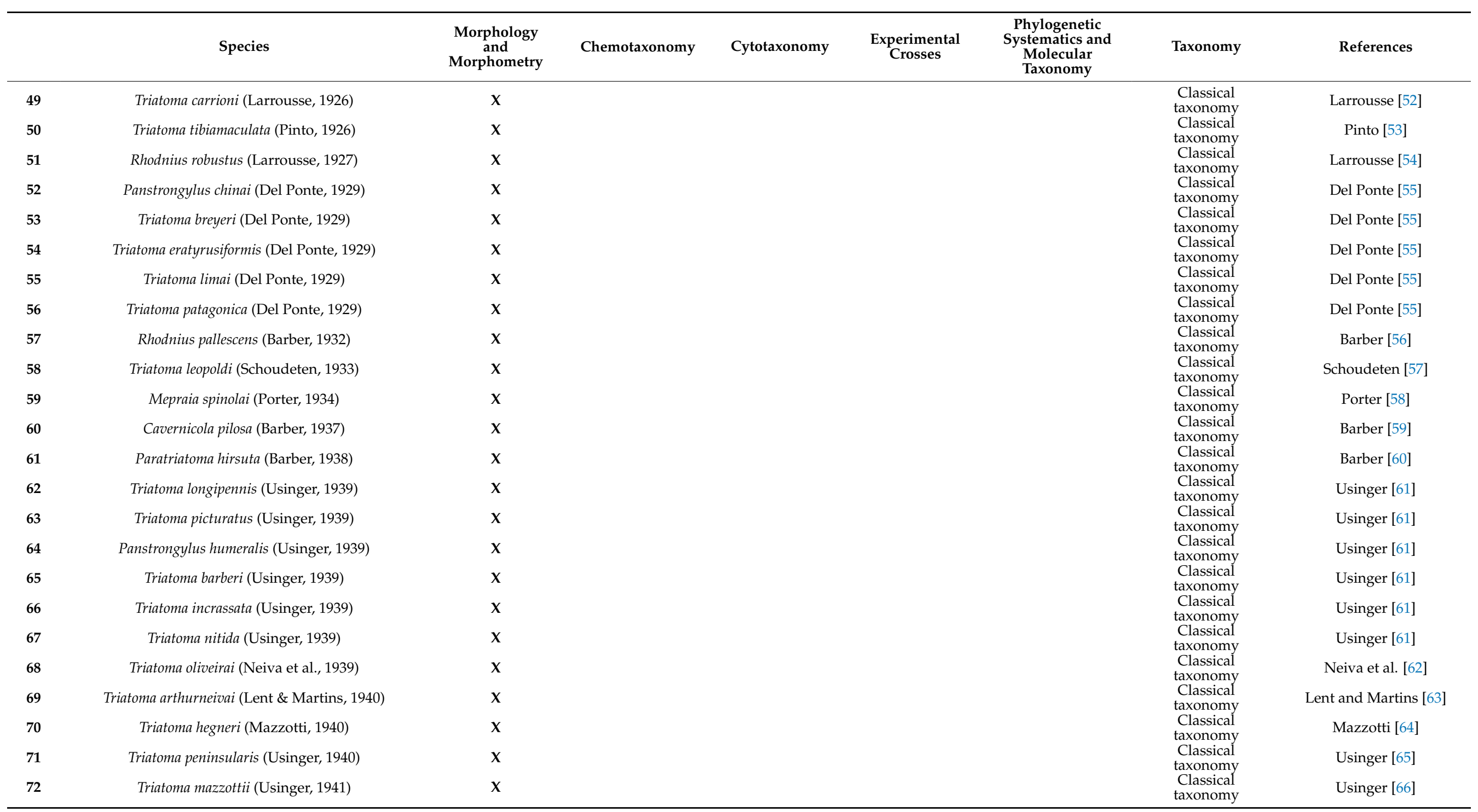


Table 2. Cont.

\begin{tabular}{|c|c|c|c|c|c|c|c|c|}
\hline & Species & $\begin{array}{c}\text { Morphology } \\
\text { and } \\
\text { Morphometry }\end{array}$ & Chemotaxonomy & Cytotaxonomy & $\begin{array}{l}\text { Experimental } \\
\text { Crosses }\end{array}$ & $\begin{array}{l}\text { Phylogenetic } \\
\text { Systematics and } \\
\text { Molecular } \\
\text { Taxonomy }\end{array}$ & Taxonomy & References \\
\hline 73 & Triatoma melanica (Neiva \& Lent, 1941) & $x$ & & & & & $\begin{array}{l}\text { Classical } \\
\text { taxonomy }\end{array}$ & Neiva and Lent [67] \\
\hline 74 & Panstrongylus tupynambai (Lent, 1942) & $x$ & & & & & $\begin{array}{l}\text { Classical } \\
\text { taxonomy }\end{array}$ & Lent [68] \\
\hline 75 & Parabelminus carioca (Lent, 1943) & $\mathrm{x}$ & & & & & $\begin{array}{l}\text { Classical } \\
\text { taxonomy }\end{array}$ & Lent [69] \\
\hline 76 & Panstrongylus diasi (Pinto \& Lent, 1946) & $x$ & & & & & $\begin{array}{l}\text { Classical } \\
\text { taxonomy }\end{array}$ & Pinto and Lent [70] \\
\hline 78 & Triatoma guasayana (Wygodzinsky \& Abalos, 1949) & $\mathrm{x}$ & & & & & $\begin{array}{l}\text { Classical } \\
\text { taxonomy }\end{array}$ & $\begin{array}{l}\text { Wygodzinsky and } \\
\text { Abalos [72] }\end{array}$ \\
\hline 79 & Triatoma dispar (Lent, 1950) & $x$ & & & & & $\begin{array}{l}\text { Classical } \\
\text { taxonomy }\end{array}$ & Lent [73] \\
\hline 80 & Triatoma wygodzinskyi (Lent, 1951a) & $x$ & & & & & $\begin{array}{l}\text { Classical } \\
\text { taxonomy }\end{array}$ & Lent [74] \\
\hline 81 & Microtriatoma trinidadensis (Lent, 1951b) & $x$ & & & & & $\begin{array}{l}\text { Classical } \\
\text { taxonomy }\end{array}$ & Lent [75] \\
\hline 82 & Triatoma amicitiae (Lent, 1951c) & $x$ & & & & & $\begin{array}{l}\text { Classical } \\
\text { taxonomy }\end{array}$ & Lent [76] \\
\hline 83 & Rhodnius neivai (Lent, 1953) & $\mathrm{x}$ & & & & & $\begin{array}{l}\text { Classical } \\
\text { taxonomy }\end{array}$ & Lent [77] \\
\hline 85 & Triatoma pugasi (Lent, 1953b) & $x$ & & & & & $\begin{array}{l}\text { Classical } \\
\text { taxonomy }\end{array}$ & Lent [79] \\
\hline 86 & Rhodnius neglectus (Lent, 1954) & $x$ & & & & & $\begin{array}{l}\text { Classical } \\
\text { taxonomy }\end{array}$ & Lent $[80]$ \\
\hline 87 & Belminus costaricencis (Herrer et al., 1954) & $x$ & & & & & $\begin{array}{l}\text { Classical } \\
\text { taxonomy }\end{array}$ & Herrer et al. [81] \\
\hline 88 & Belminus peruvianus (Herrer et al., 1954) & $\mathrm{x}$ & & & & & $\begin{array}{l}\text { Classical } \\
\text { taxonomy }\end{array}$ & Herrer et al. [81] \\
\hline 89 & Rhodnius ecuadoriensis (Lent \& León, 1958) & $\mathrm{x}$ & & & & & $\begin{array}{l}\text { Classical } \\
\text { taxonomy }\end{array}$ & Lent and León [82] \\
\hline 90 & Triatoma costalimai (Verano \& Galvão, 1958) & $\mathrm{x}$ & & & & & $\begin{array}{l}\text { Classical } \\
\text { taxonomy }\end{array}$ & Verano and Galvão [83] \\
\hline 91 & Nesotriatoma obscura (Maldonado \& Farr, 1962) & $x$ & & & & & $\begin{array}{l}\text { Classical } \\
\text { taxonomy }\end{array}$ & Maldonado and Farr [84] \\
\hline 92 & Triatoma sinaloensis (Ryckman, 1962) & $x$ & & & & & $\begin{array}{l}\text { Classical } \\
\text { taxonomy }\end{array}$ & Ryckman [85] \\
\hline 93 & Triatoma pseudomaculata (Corrêa \& Espínola, 1964) & $x$ & & & & & $\begin{array}{l}\text { Classical } \\
\text { taxonomy }\end{array}$ & Corrêa and Espínola [86] \\
\hline 94 & Psammolestes tertius (Lent \& Jurberg, 1965) & $x$ & & & & & $\begin{array}{l}\text { Classical } \\
\text { taxonomy }\end{array}$ & Lent and Jurberg [87] \\
\hline 95 & Triatoma sinica (Hsiao, 1965) & $x$ & & & & & $\begin{array}{l}\text { Classical } \\
\text { taxonomy }\end{array}$ & Hsiao [88] \\
\hline 96 & Triatoma williami (Galvão et al., 1965) & $x$ & & & & & $\begin{array}{l}\text { Classical } \\
\text { taxonomy }\end{array}$ & Galvão et al. [89] \\
\hline
\end{tabular}


Table 2. Cont.

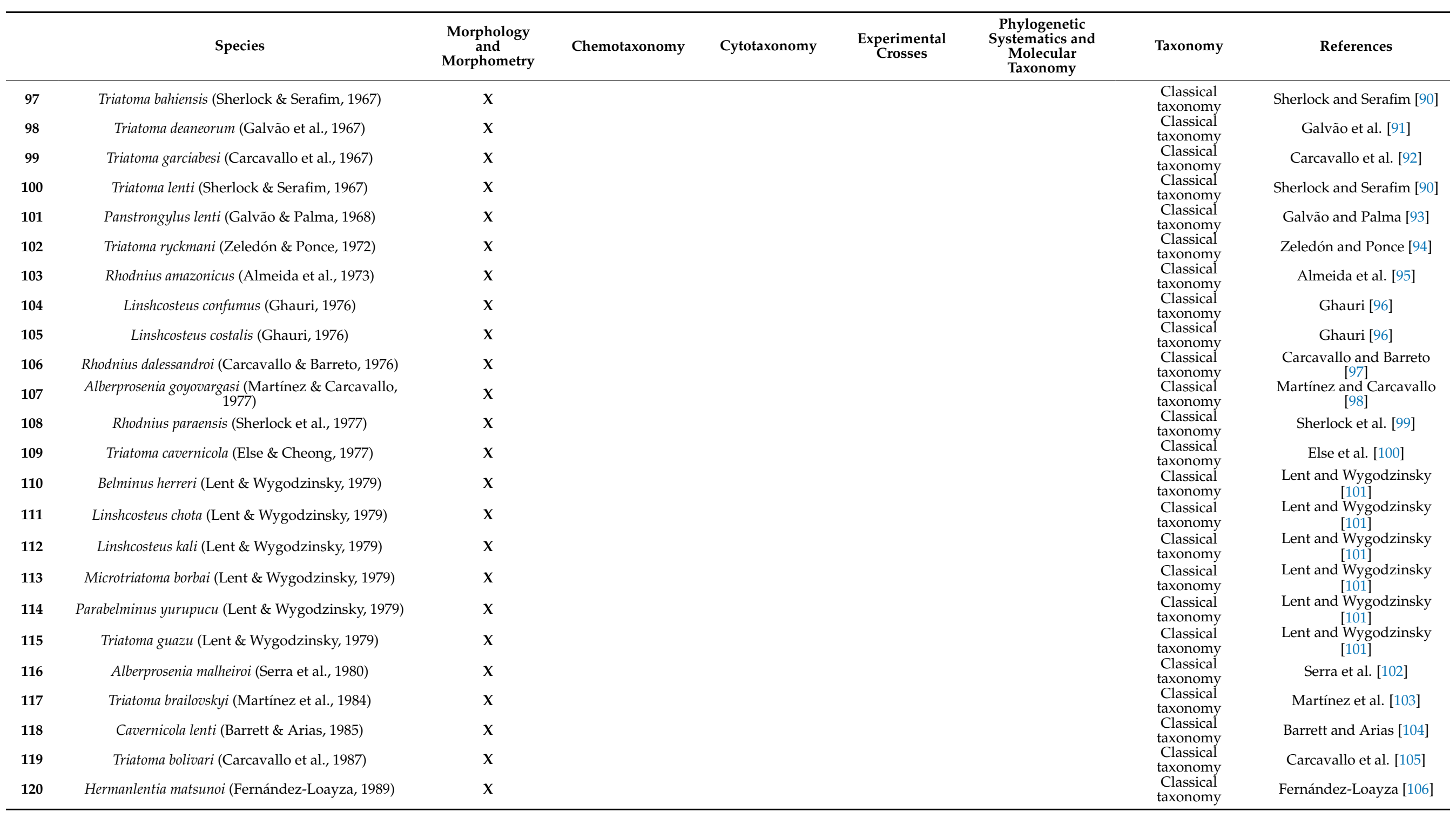


Table 2. Cont.

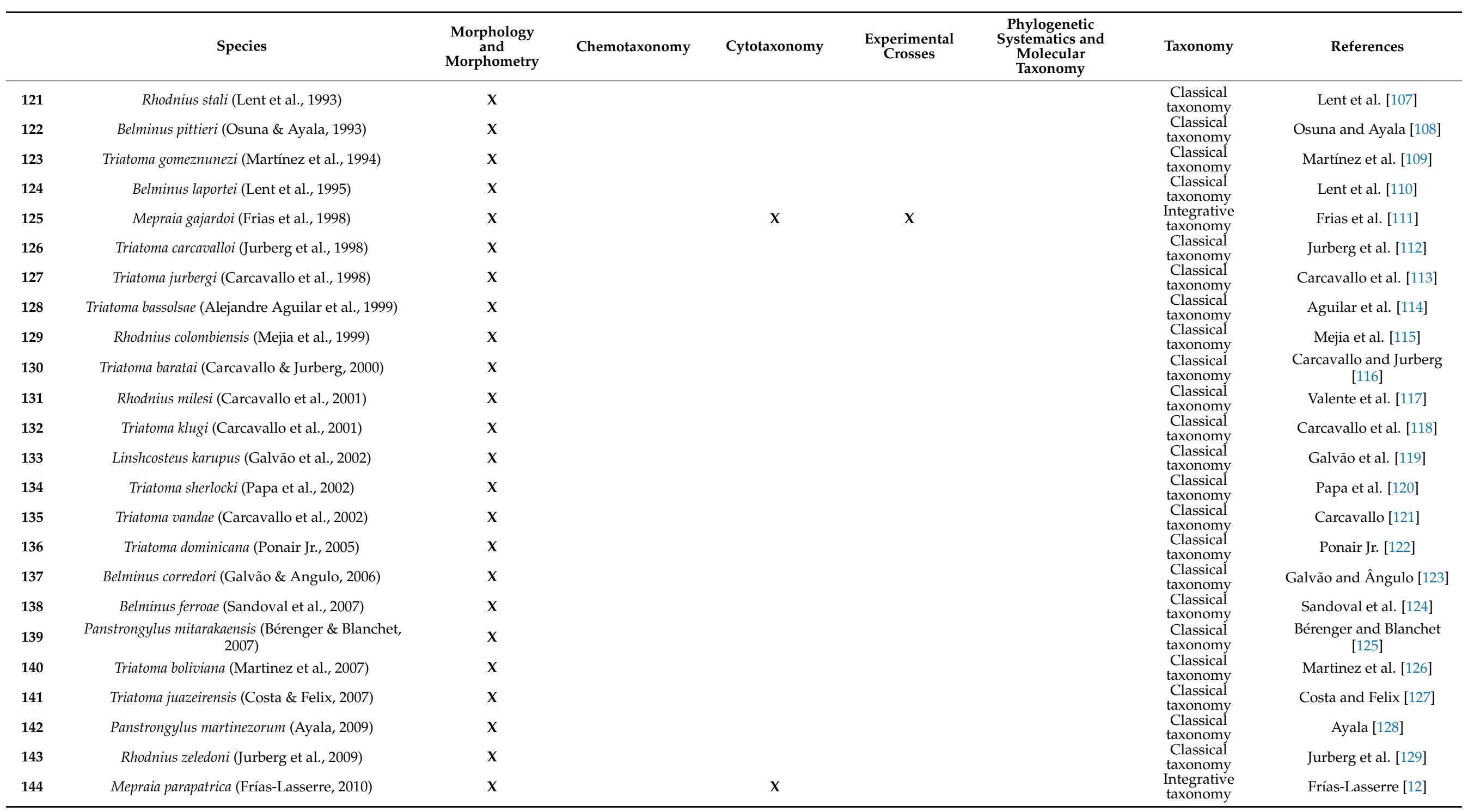


Table 2. Cont.

\begin{tabular}{|c|c|c|c|c|c|c|c|c|}
\hline & Species & $\begin{array}{l}\text { Morphology } \\
\text { and } \\
\text { Morphometry }\end{array}$ & Chemotaxonomy & Cytotaxonomy & $\begin{array}{l}\text { Experimental } \\
\text { Crosses }\end{array}$ & $\begin{array}{c}\text { Phylogenetic } \\
\text { Systematics and } \\
\text { Molecular } \\
\text { Taxonomy }\end{array}$ & Taxonomy & References \\
\hline 145 & Rhodnius montenegrensis (Rosa et al., 2012) & $x$ & & & & $x$ & $\begin{array}{l}\text { Integrative } \\
\text { taxonomy }\end{array}$ & Rosa et al. [13] \\
\hline 146 & Panstrongylus hispaniolae (Ponair Jr., 2013) & $x$ & & & & & $\begin{array}{l}\text { Classical } \\
\text { taxonomy }\end{array}$ & Ponair Jr. [130] \\
\hline 147 & Rhodnius barretti (Abad-Franch et al., 2013) & $\mathrm{x}$ & & & & $\mathrm{x}$ & $\begin{array}{l}\text { Integrative } \\
\text { taxonomy }\end{array}$ & Abad-Franch et al. [14] \\
\hline 148 & Triatoma jatai (Gonçalves et al., 2013) & $x$ & & & & & $\begin{array}{l}\text { Classical } \\
\text { taxonomy }\end{array}$ & Gonçalves et al. [131] \\
\hline 149 & Triatoma pintodiasi (Jurberg et al., 2013) & $x$ & $x$ & & & & $\begin{array}{l}\text { Integrative } \\
\text { taxonomy }\end{array}$ & Jurberg et al. [11] \\
\hline 150 & Rhodnius marabaensis (Souza et al., 2017) & $x$ & & & & $x$ & $\begin{array}{l}\text { Integrative } \\
\text { taxonomy }\end{array}$ & Souza et al. [15] \\
\hline 151 & Nesotriatoma confusa (Oliveira et al., 2018) & $x$ & & & & & $\begin{array}{l}\text { Classical } \\
\text { taxonomy }\end{array}$ & Oliveira et al. [132] \\
\hline 152 & Triatoma mopan (Dorn et al., 2018) & $x$ & & & & $x$ & $\begin{array}{l}\text { Integrative } \\
\text { taxonomy }\end{array}$ & Dorn et al. [16] \\
\hline 153 & Paleotriatoma metaxytaxa (Poinar Jr., 2019 ) & $\mathrm{x}$ & & & & & $\begin{array}{l}\text { Classical } \\
\text { taxonomy }\end{array}$ & Poinar Jr. [133] \\
\hline 154 & $\begin{array}{l}\text { Triatoma huehuetenanguensis (Lima-Cordon et al., } \\
\text { 2019) }\end{array}$ & $\mathrm{x}$ & & & & $x$ & $\begin{array}{l}\text { Integrative } \\
\text { taxonomy }\end{array}$ & Lima-Cordon et al. [17] \\
\hline 155 & Triatoma rosai (Alevi et al., 2020) & $x$ & $\mathrm{x}$ & $\mathrm{x}$ & $x$ & $\mathrm{x}$ & $\begin{array}{l}\text { Integrative } \\
\text { taxonomy }\end{array}$ & Alevi et al. [5] \\
\hline 157 & Belminus santosmalletae (Dale et al., 2021) & $x$ & & & & & $\begin{array}{l}\text { Classical } \\
\text { taxonomy }\end{array}$ & Dale et al. [7] \\
\hline
\end{tabular}




\subsection{Classical Taxonomy}

Classical taxonomy underlies most taxonomic studies of species description in the subfamily Triatominae (Table 2). The morphological and morphometric studies applied in the last described taxa are: morphological study of the head, thorax, abdomen, and male and female genitalia (with optical microscopy $(\mathrm{OM})$ and/or scanning electronic microscopy (SEM)), and morphometric study of the head, thorax, abdomen and appendices (using OM) [5-7,15-17,132].

Although the use of morphological and morphometric characters is essential to describe a new taxon (since the diagnosis of the species needs to be made based on specimens that will be deposited, such as vouchers, in entomological collections), evolutionary events of cryptic speciation [14] and phenotypic plasticity [14] present in the subfamily Triatominae can make it difficult to diagnose a taxon only by morphological studies. Classic examples of this can be seen in the genus Rhodnius Stål, 1859: R. montenegrensis Rosa et al., 2012 [13] and R. marabaensis Souza et al., 2017 [15] represent two of the four paraphyletic strains of $R$. robustus Larrousse, $1927[134,135]$ (the application of integrative taxonomy allowed description of the species from specimens initially characterized as $R$. robustus [136]). On the other hand, was demonstrated that $R$. taquarussiensis Rosa et al., 2017 (species described by integrative taxonomy [20]) represented only an intraspecific polymorphism of $R$. neglectus Lent, 1954 [19] (from studies of molecular taxonomy combined with experimental crosses it was possible to synonymize the species [19]).

Morphological convergence events can also hinder the classic taxonomy of these vectors [129]. The paraphyletic genus Triatoma Laporte, 1832 needs several studies from a taxonomic and systematic point of view [137]. Triatoma tibiamaculata (Pinto, 1926), for example, is a species that has morphological characteristics that bring it together and groups it (until now) as a Triatoma [138]. However, the generic status of this vector has been questioned several times $[134,137,138]$ — since it presents cytogenetic [139], structural [140] and phylogenetic $[137,138]$ characteristics that bring it closer to Panstrongylus (which highlights the importance of studies with integrative taxonomy).

\subsection{Molecular Taxonomy}

The first phylogenetic trees with molecular markers were published only in 1998 [141], giving rise to the phylogenetic systematics and molecular taxonomy of these vectors. Although no species of triatomine has been described by molecular taxonomy (Table 2), the combination of phylogenetic analyses with morphological and morphometric studies in species description studies (integrative taxonomy) has been a trend in the last decade [5,13-17] (Table 2), since it provides greater reliability of the specific status of the taxa and allows, above all, to understand the evolutionary history of the species.

In addition to the contributions mentioned above, molecular taxonomy and phylogenetic systematics allowed the evaluation and re-validation of the taxonomic status of some species: reinclusion of Linshcosteus Distant, 1904 genus in Triatomini tribe (extinguishing the Linshcosteini tribe) [30]; inclusion of Psammolestes Bergroth, 1911 species in the genus Rhodnius [30] (proposal not accepted by the scientific community due to the differences that support the generic status of Psammolestes [17]); inclusion of the species T. flavida Neiva, 1911, and N. obscura Maldonado \& Farr, 1962 in the genus Nesotriatoma Usinger, 1944 [142]; confirmation of the generic status of Nesotriatoma [132]; inclusion of species T. spinolai Porter, 1934, M. gajardoi Frias, Henry \& Gonzalez, 1998, T. eratyrusiformis Del Ponte, 1929, and T. breyeri Del Ponte, 1929 in the genus Mepraia Mazza, Gajardo \& Jörg, 1940 [142] (partially accepted suggestion, being the Mepraia genus currently composed of M. spinolai, M. gajardoi, and M. parapatrica Frías-Lasserre, 2010 [4,143]); confirmation of the generic status of Mepraia [137]; and inclusion of T. dimidiata (Latreille, 1811) in the Meccus Stål, 1859 genus (genus that later was considered invalid and the Meccus species started to be considered as Triatoma $[137,144,145])$.

Although the International Code of Zoological Nomenclature does not consider groupings of triatomines to be complexes or subcomplexes [146], Justi et al. [137] suggests that 
these groupings should represent monophyletic groups. In the genus Triatoma, for example, studies based on phylogenetic systematics evaluated the position of several species that had been grouped mainly by geographic distribution and morphological similarities and proposed regrouping and/or the creation of new monophyletic groups [137,147,148]. Species well defined as natural groups (monophyletic) are currently the T. brasiliensis $[149,150], T$. sordida [151], T. rubrovaria [151], T. infestans [137], and T. vitticeps [148] subcomplexes.

\subsection{Integrative Taxonomy}

The data integration in the integrative taxonomy can be done by cumulation or congruence [152]. The use of combined tools to delimit a species of triatomine occurred for the first time in 1998 by Frias et al. [111] who combined morphological, morphometric, cytogenetic, and reproductive barriers data to describe M. gajardoi (Table 2). However, only in the last decade has the integrative taxonomy has been more applied in the study of these vectors (Table 2).

This tendency to integrate different analyses to characterize a taxon, made it possible to resolve ancient taxonomic issues, such as the description by T. mopan Dorn et al. (2018) and T. huehuetenanguensis Lima-Cordón et al. (2019) from specimens initially characterized as T. dimidiata $[16,17,153,154]$ and the recent description of T. rosai Alevi et al., 2020 from the allopatric population of T. sordida (Stål, 1859) from Argentina $[5,155,156]$. In addition, the specific status of T. bahiensis Sherlock \& Serafim, 1967 (a species that for more than three decades has been synonymous with T. lenti Sherlock \& Serafim, 1967 [101]) has been revalidated based on integrative taxonomy [149].

On the other hand, even if the integrative taxonomy provides more robustness in the characterization of the new taxa (decreasing the chance of synonymization), does not prevent this event can occur (as mentioned above for $R$. taquarussuensis which has been synonymous with $R$. neglectus Lent, 1954 [19]). Although morphological, morphometric, and cytogenetic intraspecific variation had been described in the genus Rhodnius [157,158], the description of R. taquarussuensis was based on these factors [20]. Thus, synonymization event occurred through phylogenetic analyses and experimental crosses [19]. We suggest that integrative taxonomy work should include molecular studies and, whenever possible, reproductive barriers to confirm the taxon specific status following the biological concept of species [159-161].

In general, most articles of description based on integrative taxonomy combine only morphological and morphometric data with molecular analyses (Table 2). However, it is worth mentioning that in 2020 the description of T. rosai was published based on morphometric, morphological, molecular data, and experimental crosses that have been combined with information from the literature about the species (cytogenetic data [155,156], electrophoresis pattern [155], cuticular hydrocarbons pattern [162], geometric morphometry [163], cycle, and average time of life [164-166] as well as geographic distribution [18,42-44,50,51]), becoming the most complete article of species description of the subfamily Triatominae [5].

\section{Overview of Tools Applied to Taxonomic Studies of Triatomines}

In addition to species descriptions, several taxonomic studies have been carried out to assess the specific status of valid species and, above all, to assist in the correct classification of Chagas disease vectors. Based on this, we will specifically discuss the application of each taxonomic tool.

\subsection{Morphology and Comparative Morphology}

As already mentioned above, morphological studies are applied to all formal species descriptions (Table 2). These analyses can characterize several structures that, in general, are compared and confirm the specific status of triatomines [5,6,11-17]. Studies with OM and SEM allow characterizing structures of the head, thorax, and abdomen. These analyses are very important for classical taxonomy and support the main dichotomous keys used for the correct identification of these vectors [101,167-172]. 


\subsection{Morphometry}

Like morphological studies, morphometric studies are also present in the description of all triatomines (at first, showing the size of specimens and structures and, later, by means of geometric morphometry [4]). These measurable data are very important from a taxonomic point of view, as a visual identification system was recently developed from morphometric data that has the potential to automate the identification of triatomines $[173,174]$.

\subsection{Chemotaxonomy}

In 1964, Actis et al. [175] used, for the first time, biochemical studies with hemolymph protein electrophoresis to compare species of triatomines, giving rise to chemotaxonomy. Isoenzymes were applied to different species of Rhodnius [176], the T. brasiliensis subcomplex [177] and Mexican Triatoma [178]. However, recently, biochemical studies are rare from a taxonomic perspective; they contribute to the integrative taxonomy as shown by Jurberg et al. [11] and Alevi et al. [5] with the species descriptions of T. pintodiasi Jurberg et al., 2013 and $T$. rosai respectively.

\subsection{Cytotaxonomy and Karyosystematic}

Cytotaxonomy was started with Ueshima [179] by proposing the application of cytogenetic studies of chromosomes to differentiate morphologically related species. Later, the use of chromosomal analyses — such as karyotypes [180-183] - the constitutive heterochromatin pattern [156,184,185], the heterochromatin base pair composition [186-188], and the location of the nucleolar organizing region [139,156,189], assisted in the correct identification and classification of triatomines. Recently, dichotomous keys have been proposed based on cytogenetic data [190-193].

\subsection{MALDI-TOF MS}

Laroche et al. [194] used, for the first time, matrix-assisted laser desorption/ionization time-of-flight mass spectrometry (MALDI-TOF MS) analysis to differentiate triatomine species. The researchers were able to differentiate species from French Guiana by MALDITOF. Subsequently, Souza et al. [195] used these analyses to differentiate 12 species of the genus Rhodnius. Furthermore, Souza et al. [196] also differentiated the species of Cavernicola Barber, 1937.

\subsection{Omics}

In 2017, omics tools (transcriptomics) were used for the first time in taxonomic studies of triatomines to confirm the specific status of R. montenegrensis [197]. In 2019, Brito et al. [198] also validated the specific status of $R$. montenegrensis and confirmed that this species refers to strain II of the paraphyletic group of $R$. robustus.

\section{Concluding Remarks}

Classical taxonomy, over the last few decades, has been revitalized by integrative taxonomy leading to success in the identification and delimitation of new species through the use of multiple and complementary approaches. Most descriptions of triatomine species are based on classical taxonomy. Facing evolutionary (cryptic speciation and phenotypic plasticity) and taxonomic (more than 190 synonymizations) problems has indicated that it is evident that integrative taxonomy studies are an important and necessary trend for this group of vectors. However, from the synonymization of R. taquarussuensis (which was described through integrative taxonomy [20] and was later synonymized with R. neglectus [19]), it is evident that phylogenetic studies (molecular taxonomy) should be considered among the analyses used for the description of new species from the integrative taxonomy (Figure 1). 


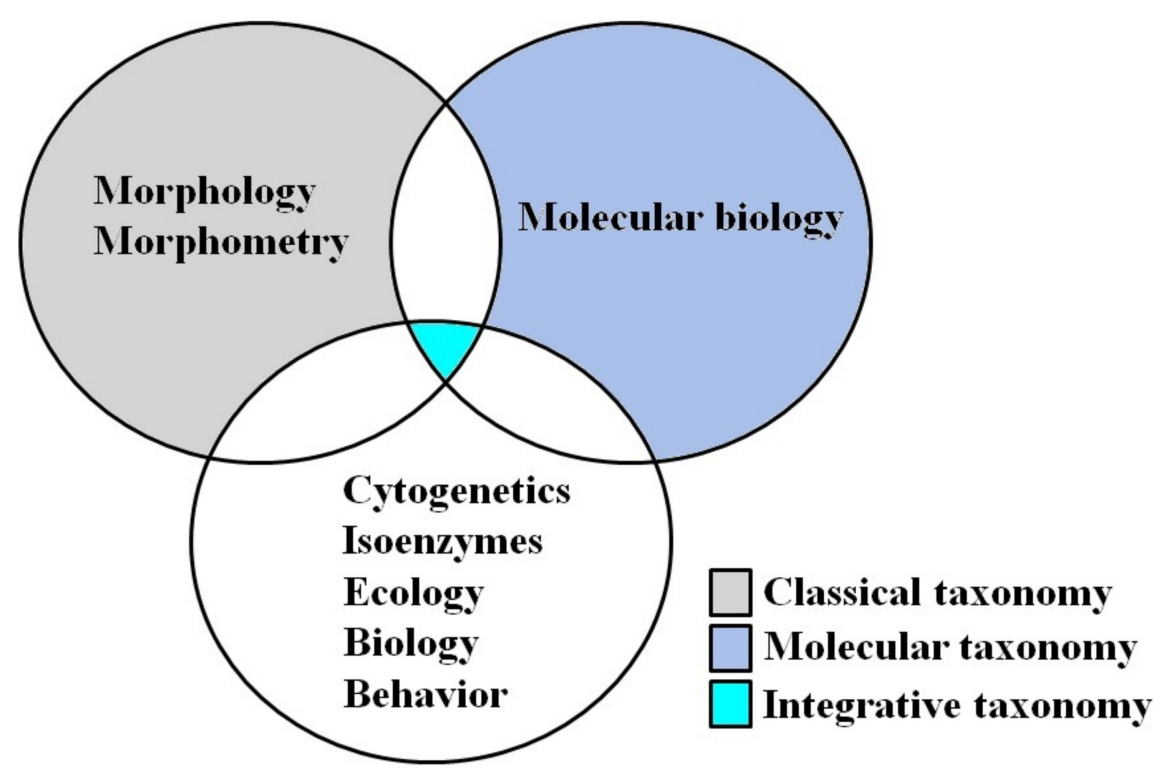

Figure 1. Schematic representation of the integrative taxonomy of triatomines.

Author Contributions: Conceptualization, K.C.C.A., J.d.O., D.d.S.R. and C.G.; Writing-original draft preparation, K.C.C.A., J.d.O., D.d.S.R. and C.G.; Writing-review and editing, K.C.C.A., J.d.O., D.d.S.R. and C.G. All authors have read and agreed to the published version of the manuscript.

Funding: This research was funded by São Paulo Research Foundation, Brazil (FAPESP) (Process number 2017/05015-7 and 2019/02145-2), the Coordination for the Improvement of Higher Education Personnel, Brazil (CAPES)_Finance Code 001 and the National Council for Scientific and Technological Development, Brazil (CNPq).

Institutional Review Board Statement: Not applicable.

Informed Consent Statement: Not applicable.

Data Availability Statement: All relevant data are within the manuscript.

Conflicts of Interest: The authors declare no conflict of interest.

\section{References}

1. World Health Organization. Available online: https://www.who.int/news-room/fact-sheets/detail/chagasdisease-(americantrypanosomiasis) (accessed on 28 October 2021).

2. Pan American Health Organization. Available online: https://www.paho.org/en/topics/chagas-disease (accessed on 26 November 2021).

3. Justi, S.A.; Galvão, C. The Evolutionary Origin of Diversity in Chagas Disease Vectors. Trends Parasit. 2017, 33, 42-52. [CrossRef] [PubMed]

4. Galvão, C. Taxonomia dos Vetores da Doença de Chagas da Forma à Molécula, quase três séculos de história. In Atualidades em Medicina Tropical no Brasil: Vetores, 1st ed.; Oliveira, J., Alevi, K.C.C., Camargo, L.M.A., Meneguetti, D.U.O., Eds.; Stricto Sensu Editora: Rio Branco, Brasil, 2020; pp. 9-37. (In Portuguese)

5. Alevi, K.C.C.; Oliveira, J.; Garcia, A.C.C.; Cristal, D.C.; Delgado, L.M.G.; Bittinelli, I.F.; Reis, Y.V.; Ravazi, A.; Oliveira, A.B.B.; Galvão, C.; et al. Triatoma rosai sp. nov. (Hemiptera, Triatominae): A New Species of Argentinian Chagas Disease Vector Described Based on Integrative Taxonomy. Insects 2020, 11, 830. [CrossRef] [PubMed]

6. Zhao, Y.; Galvão, C.; Cai, W. Rhodnius micki, a new species of Triatominae (Hemiptera, Reduviidae) from Bolivia. ZooKeys 2021, 1012, 71-93. [CrossRef] [PubMed]

7. Dale, C.; Justi, S.A.; Galvão, C. Belminus santosmalletae (Hemiptera: Heteroptera: Reduviidae): New Species from Panama, with an Updated Key for Belminus Stål, 1859 Species. Insects 2021, 12, 686. [CrossRef] [PubMed]

8. De Geer, C. Mémoires pour Servir à l'Historie des Insectes; L.L. Grefing: Stockholm, Sweden, 1773; pp. 1-696. (In French)

9. Dayrat, B. Towards integrative taxonomy. Biol. J. Linn. Soc. 2005, 85, 407-415. [CrossRef]

10. Will, K.W.; Mishler, B.D.; Wheeler, Q.D. The perils of DNA barcoding and the need of integrative taxonomy. System. Biol. 2005, 54, 844-851. [CrossRef] 
11. Jurberg, J.; Cunha, V.; Cailleaux, S.; Raigorodschi, R.; Lima, M.S.; Rocha, D.S.; Moreira, F.F.F. Triatoma pintodiasi sp. nov. do subcomplexo T. rubrovaria (Hemiptera, Reduviidae, Triatominae). Rev. Pan Amaz. Saúde 2013, 4, 43-56. [CrossRef]

12. Frías-Lasserre, D. A new species and karyotype variation in the bordering distribution of Mepraia spinolai (Porter) and Mepraia gajardoi Frías et al. (Hemiptera: Reduviidae: Triatominae) in Chile and its parapatric model of speciation. Neotrop. Entom. 2010, 39, 572-583. [CrossRef]

13. Rosa, J.A.; Rocha, C.S.; Gardim, S.; Pinto, M.C.; Mendonça, V.J.; Ferreira Filho, J.C.R.; Carvalho, E.C.; Camargo, L.M.A.; Oliveira, J.; Nascimento, J.D.; et al. Description of Rhodnius montenegrensis n. sp. (Hemiptera: Reduviidae:Triatominae) from the state of Rondônia, Brazil. Zootaxa 2012, 347, 62-76. [CrossRef]

14. Abad-Franch, F.; Pavan, M.G.; Jaramillo-O, N.; Palomeque, F.S.; Dale, C.; Chaverra, D.; Monteiro, F. A Rhodnius barretti, a new species of Triatominae (Hemiptera: Reduviidae) from western Amazonia. Mem. Inst. Oswaldo Cruz 2013, 108, 92-99. [PubMed]

15. Souza, E.S.; Von Atzingen, N.C.N.; Furtado, M.B.; Oliveira, J.; Nascimento, J.D.; Vendrami, D.P.; Gardim, S.; Rosa, J.A. Description of Rhodnius marabaensis sp. n. (Hemiptera, Reduviidae, Triatominae) from Pará State, Brazil. ZooKeys 2016, 621, 45-62.

16. Dorn, P.L.; Justi, A.S.; Dale, C.; Stevens, L.; Galvão, C.; Cordon, R.L.; Monroy, C. Description of Triatoma mopan sp. n. from a cave in Belize (Hemiptera, Reduviidae, Triatominae). ZooKeys 2018, 775, 69-95. [CrossRef]

17. Lima-Cordón, R.A.; Monroy, M.C.; Stevens, L.; Rodas, A.; Rodas, G.A.; Dorni, P.L.; Justi, A.S. Description of Triatoma huehuetenanguensis sp. n., a potential Chagas disease vector (Hemiptera, Reduviidae, Triatominae). ZooKeys 2019, 820, 51-70. [CrossRef]

18. Galvão, C.; Carcavallo, R.; Rocha, D.S.; Jurberg, J. A checklist of the current valid species of the subfamily Triatominae Jeannel, 1919 (Hemiptera, Reduviidae) and their geographical distribution, with nomenclatural and taxonomic notes. Zootaxa 2003, 202, 1-36. [CrossRef]

19. Nascimento, J.D.; Rosa, J.A.; Salgado-Roa, F.C.; Hernández, C.; Pardo-Diaz, C.; Alevi, K.C.C.; Ravazi, A.; Oliveira, J.; AzeredoOliveira, M.T.V.; Salazar, C.; et al. Taxonomical over splitting in the Rhodnius prolixus (Insecta: Hemiptera: Reduviidae) clade: Are R. taquarussuensis (da Rosa et al., 2017) and R. neglectus (Lent, 1954) the same species? PLoS ONE 2019, 14, e0213043. [CrossRef]

20. Rosa, J.A.; Justino, H.H.G.; Nascimento, J.D.; Mendonça, V.J.; Rocha, C.S.; Carvalho, D.B.; Falcone, R.; Azeredo-Oliveira, M.T.V.; Alevi, K.C.C.; Oliveira, J. A new species of Rhodnius from Brazil (Hemiptera, Reduviidae, Triatominae). ZooKeys 2017, $675,1-25$. [CrossRef] [PubMed]

21. Latreille, P.A. Insectes de líAmérique recueillis pendant le voyage de MM. In Voyage aux Régions Équinoxiales du Nouveau Continent; Humboldt, A., Bonpland, A., Eds.; 1811; pp. 197-397. (In French)

22. Klug, J.C.F. Reise um die Erde, in den Jahren 1830, 1831, und 1832, Ausgefürht von F.J.F.Meyen. Teil 1; C. W. Eichhoff: Berlin, Germany, 1834. (In German)

23. Burmeister, H. Handbuch der Entomologie; Tome 2, part 1; T. Enslin: Berlin, Germany, 1835; p. 400. (In German)

24. Blanchard, E. Hémiptères. In D'Orbigny, A. [1837-1846], Voyage dans L'Amérique Méridionale, Tome Sixiéme, 2.e Partie: Insectes; Chez. P. Bertrand: Paris, France, 1846; pp. 218-222. (In French)

25. Erichson, W.F. Insecten. In Schomburgk, R. Reisen in Britisch-GUIANA in der jahren 1840-1844 im auftrag Sr Majestat des Konings von Pruessen; Weber: Leipzig, Germany, 1848; pp. 553-617. (In German)

26. Herrich-Schaeffer, G.H.W. Die Wanzenartigen Insekten; C. H. Zehschen Buchhandlung: Nurnberg, Germany, 1848 ; p. 130. (In German)

27. Leconte, J.L. Remarks on two species of American Cimex. Proc. Acad. Nat. Sci. Phila. 1855, 7, 404.

28. Stål, C. Monographie der Gattung Conorhinus und Verwandten. Berliner Entomol Zeitschrift 1859, 3, 99-117. (In German) [CrossRef]

29. Stål, C. Hemiptera Fabriciana; Pars 1. In Heteroptera; Kongliga Svenska Vetenskaps-Akademiens: Stockholm, Sweden, 1868; pp. 1-148. (In Swedish)

30. Stål, C. Enumeratio Hemipterorum; Pars 2. Kongliga Svenska Vetenskaps-Akademiens: Stockholm, Sweden, $1872 ;$ pp. 1-159.

31. Walker, F. Catalogue of the Specimens of Hemiptera Heteroptera in the Collection of the British Museum; BM(NH): London, UK, 1873; p. 220.

32. Berg, C. Hemiptera Argentina Enumeravit Speciesque Novas; P. E. Coni: Buenos Aires, Argentina, 1879; p. 316.

33. Uhler, P.R. Observations upon the Heteropterous Hemiptera of Lower California, with description of new species. Proc. Calif. Acad. Sci. 1894, 4, 223-295.

34. Champion, G.C. Insecta Rhynchota. Hemiptera-Heteroptera. In Biologia Centrali-Americana; Porter, R.H., Ed.; W. L. Distant: London, UK, 1899; p. 416.

35. Breddin, G. Neue Paläotropische Reduviinen. Sber. Ges. Naturf. Freunde Berl. 1903, 3, 111-129.

36. Distant, W.L. The Fauna of British India, Including Ceylon and Burma. Rhynchota; Taylor \& Francis: London, UK, 1904; Volume 2, $503 p$.

37. Valdés, P.R. Clasificación Gundlach de Hemipteros Cubanos, conforme a los ejemplares que existen en el Museo del Instituto de 2a enseñanza de La Habana. Anales de la Academia de Ciencias Médicas, Físicas y Naturales de la Habana 1910, 46, 425-446. (In Spanish)

38. Neiva, A. Notas de entomología médica. Duas novas espécies norte-americanas de hemípteros hematophagos. Brasil-Médico 1911, 25, 421-422. (In Portuguese)

39. Bergroth, E. A new genus of Reduviidae. Psyche 1911, 18, 144-145. [CrossRef]

40. Neiva, A. Zwei neue Afrikanische Arten des Genus Triatoma (oder Conorhinus). Proc. Entomol. Soc. Wash. 1911, 13, 239-240. (In German) 
41. Neiva, A. Contribuição para o estudo dos hematophagos brasileiros e descrição de uma nova espécie de Triatoma. Brasil-Médico 1911, 25, 461-462. (In Portuguese)

42. Neiva, A. Notas de entomología médica. Três novas especies de reduvidas norte-americanas. Bras. Méd. 1911, $25,441$. (In Portuguese)

43. Neiva, A. Notas de entomología médica e descripção de duas novas espécies de Triatomas norte-americanas. Bras. Méd. 1912, 26, 21-22. (In Portuguese)

44. Neiva, A. Algunos datos sobre hemípteros hematófagos de la América del sur, con la descripción de una nueva especie. Anales del Museo Nacional de Historia Natural 1913, 24, 195-198. (In Spanish)

45. Matta, A. Um novo Reduvido do Amazonas, Rhodnius brethesi n. sp. Amaz. Méd. 1919, 2, 93-94. (In Portuguese)

46. Neiva, A.; Pinto, C. Dos hemípteros hematophagos do Norte do Brasil com descrição de duas novas espécies. Bras. Méd. 1923, 1923, 73-76. (In Portuguese)

47. Neiva, A.; Pinto, C. Estado actual dos conhecimentos sôbre o gênero Rhodnius Stål, com a descripção de uma nova espécie. Bras. Méd. 1923, 37, 20-24. (In Portuguese)

48. Neiva, A.; Pinto, C. Representantes dos gêneros Triatoma Lap. e Rhodnius Stål, encontrados no Brasil Central e Sul; observações biológicos e descripção de uma nova espécie. Bras. Méd. 1923, 37, 84-86. (In Portuguese)

49. Larrousse, F. Triatomes díAsie: Description díune nouvelle espèce Triatoma bouvieri n. sp. Annales de Parasitologie Humaine et Comparée 1924, 2, 62-70. (In Spanish) [CrossRef]

50. Pinto, C.; Barreto, J.B. Uma nova espécie de "barbeiro" do Brasil, (Triatoma petrochii n.s p.). Sci. Med. 1925, 3, 769. (In Portuguese)

51. Pinto, C. Triatomideos da Venezuela, com a descripção de uma nova espécie do gênero Eutriatoma. Ann. Fac. Med. São Paulo 1926, 1, 85-87. (In Portuguese)

52. Larrousse, F. Description de deux espéces nouvelles du genre Triatoma: T. carrioni n. sp., et T. pintoi n. sp. Annales de Parasitologie Humaine et Comparée 1926, 4, 136-139. (In Spanish) [CrossRef]

53. Pinto, C. Eutriatoma tibiamaculata novo género e nova espécie, forma intermediaria entre Rhodnius e Triatoma. Sci. Med. 1926, 3 , 133-136. (In Portuguese)

54. Larrousse, F. Etude biologique et systématique du genre Rhodnius Stål (Hémiptères, Reduviidae). Annales de Parasitologie 1927, 5, 63-88. (In French)

55. Del Ponte, E. Algunas especies nuevas del género Triatoma Lap. Boletin de la Sociedad Entomológica Argentina 1929, 1, 3-8. (In Spanish)

56. Barber, H.G. A new species of Rhodnius from Panama (Hemiptera: Reduviidae). J. Wash. Acad. Sci. 1932, 22, 514-517.

57. Schoudeten, H. Résultats scientifiques du voyage de LL. AA. RR. le Prince et la Princesse de Belgique. Hemiptera ñ Heteroptera. Memoires du Musee Royal dí Histoire Naturelle Belgique 1933, 4, 43-70. (In French)

58. Porter, C.E. Una Triatoma nueva chilena. Revista Chilena de Historia Natural 1934, 37, 192-193. (In Spanish)

59. Barber, H.G. A new bat-cave bug from Panama (Hemiptera-Heteroptera, Reduviidae). Proc. Entomol. Soc. Wash. 1937, 39, 60-63.

60. Barber, H.G. A new genus and species of the subfamily Triatominae (Reduviidae: Hemiptera). Proc. Entomol. Soc. Wash. 1938, 40, 104-105.

61. Usinger, R.L. Descriptions of new Triatominae with a key to genera (Hemiptera, Reduviidae). Univ. Calif. Publ. Entomol. 1939, 7 , 33-56.

62. Neiva, A.; Pinto, C.; Lent, H. Notas sobre triatomideos do Rio Grande do sul e descrição de uma nova espécie. Memórias do Instituto Oswaldo Cruz 1939, 34, 607-610. (In Spanish) [CrossRef]

63. Lent, H.; Martins, A.V. Estudos sôbre os triatomídeos do Estado de Minas Gerais, com descrição de uma espécie nova. Rev. Entomol. 1940, 11, 877-886. (In Portuguese)

64. Mazzottii, L. Una nueva especie de Triatoma en Mexico. Cien Méx. 1940, 1, 22-23. (In Spanish)

65. Usinger, R.L. A new Triatoma from Lower California (Hemiptera, Reduviidae). Pan Pacific Ent. 1940, 16, 73-74.

66. Usinger, R.L. Notes and descriptions of neotropical Triatominae (Hemiptera, Reduviidae). Pan Pacific Ent. 1941, $17,49-57$.

67. Neiva, A.; Lent, H. Sinopse dos Triatomideos. Rev. Ent. 1941, 12, 61-92. (In Spanish)

68. Lent, H. Estudos sobre os triatomideos do Estado do Rio Grande do Sul, com descrição de uma espécie nova. Rev. Bras. Biol. 1942, 2, 219-231. (In Portuguese)

69. Lent, H. Novo transmissor da doença de Chagas na cidade de Rio de Janeiro, D.F. Estudo dos gêneros Belminus Stål, 1859, Bolbodera Valdés, 1910 e descrição de Parabelminus carioca n.g., n. sp. (Hemiptera, Triatomidae). Memórias do Instituto Oswaldo Cruz 1943, 38, 497-516. (In Portuguese) [CrossRef]

70. Pinto, C.; Lent, H. Novo hemíptero hematófago do gênero Panstrongylus Berg, 1879. Rev. Bras. Biol. 1946, 6, 459-465. (In Portuguese)

71. Romaña, C.; Abalos, J. Triatoma delpontei n. sp. (Hemiptera, Reduviidae). Anales del Inst. de Med. Reg. Tucumán. 1947, 2, 79-93.

72. Wygodzinsky, P.; Abalos, J.W. Triatoma guasayana sp. n. (Triatominae, Reduviidae, Hemiptera) (Nota previa). Semana Médica 1949, $56,2$.

73. Lent, H. Nova espécie de Triatoma Laporte, 1833 (Hemiptera, Reduviidae). Rev. Bras. Biol. 1950, 10, 437-440. (In Portuguese)

74. Lent, H. Novo Triatoma do Estado de Minas Gerais (Brasil) (Hemiptera, Reduviidae). Rev. Entom. 1951, $22,349-352$. (In Portuguese) 
75. Lent, H. Segunda espécie do gênero Bolbodera Valdés, 1910 (Hemiptera, Reduviidae). Rev. Bras. Biol. 1951, 11, 153-156. (In Portuguese)

76. Lent, H. Triatominae das regiões Oriental, Australiana, Etiópica e Paleártica, com descrição de uma nova espécie (Hemiptera, Reduviidae). Rev. Bras. Biol. 1951, 11, 425-429. (In Portuguese)

77. Lent, H. Um novo hemiptero hematófago da Venezuela (Reduviidae, Triatominae). Rev. Bras. Biol. 1953, 13, 169-172. (In Portuguese)

78. Leite, I.C.; Barbosa, A. Triatoma (Eutriatoma) matogrossensis n sp. Bol. do Inst. Oswaldo Cruz 1953, 2, $123-126$.

79. Lent, H. Nova espécie de Triatoma da Região Oriental (Hemiptera, Reduviidae). Rev. Bras. de Biol. 1953, 13, 315-319. (In Portuguese)

80. Lent, H. Comentários sôbre o gênero Rhodnius Stål com descrição de uma nova espécie do Brasil (Hemiptera, Reduviidae). Rev. Bras. de Biol. 1954, 14, 237-247. (In Portuguese)

81. Herrer, A. Contribución al conocimiento del género Belminus Stål, 1859 (Triatominae, Reduviidae, Hemiptera). Anales del Inst. de Med. Reg. Tucumán. 1954, 4, 85-105. (In Spanish)

82. Lent, H.; León, L.A. Um novo Rhodnius Stål do Ecuador (Hemiptera, Reduviidae). Rev. Bras. Biol. 1958, 18, 181-185. (In Portuguese)

83. Verano, O.T.; Galvão, A.B. Triatoma costalimai n. sp. Rev. Bras. Mal. Doenças Trop. 1958, 10, $199-205$.

84. Maldonado, J.; Farr, T.H. On some Jamaican Triatominae and Emesinae. Proc. Entomol. Soc. Wash. 1962, 64, 187-194.

85. Ryckman, R.E. Biosystematics and hosts of the Triatoma protracta complex in NorthAmerica (Hemiptera: Reduviidae) (Rodentia: Cricetidae); University of California Press: Oakland, CA, USA, 1962; Volume 27, pp. 93-240.

86. Correa, R.R.; Espínola, H.N. Descrição de Triatoma pseudomaculata, nova espécie de triatomíneo de Sobral, Ceará (Hemiptera, Reduviidae). Arquivos de Higiene e Saude Publica 1964, 29, 115-127. (In Portuguese)

87. Lent, H.; Jurberg, J. O gênero Psammolestes Bergroth, 1911, com um estudo sôbre a genitália das espécies (Hemiptera, Reduviidae, Triatominae). Rev. Bras. Biol. 1965, 25, 349-376. (In Portuguese)

88. Hsaio, T.Y. A new species of Triatoma Laporte (Hemiptera, Reduviidae). Acta Zootax. Sinica 1965, 2, 197-200.

89. Galvão, A.B.; Silva e Souza, H.; Lima, R.R. Triatoma williami n. sp. (Hemiptera, Triatominae). Rev. Bras. Mal. Doenças Trop. 1965, $17,363-366$.

90. Sherlock, I.A.; Serafim, M. Triatoma lenti sp. n., Triatoma pessoai sp. n. e Triatoma bahiensis sp. n. do estado da Bahia, Brasil (Hemiptera, Reduviidae). Gaz. Méd. Bahia. 1967, 67, 75-92. (In Portuguese)

91. Galvão, A.B.; Souza, H.A.S.; Lima, R.R. Especies de Triatominae ocorrentes em Goias e descrição de uma nova especie. Revista Brasileira de Malariologia e Doenças Tropicais 1967, 19, 397-412. (In Portuguese)

92. Carcavallo, R.U.; Cichero, J.A.; Martínez, A.; Prosen, A.F.; Ronderos, R. Una nueva espécie del género Triatoma Laporte (Hemiptera, Reduviidae, Triatominae). Segundas Jornadas Entomoepidemiológicas Argentinas 1967, 2, 43-48. (In Spanish)

93. Galvão, A.B.; Palma, J.D. Uma nova espécie do genero Panstrongylus Berg, 1879 (Reduviidae, Triatominae). Rev. Bras. Biol. 1968, 28, 403-405. (In Portuguese)

94. Zeledón, R.; Ponce, C. Descripción de una nueva especie de Triatoma de Honduras, América Central (Hemiptera, Reduviidae). Rev. Biol. Trop. 1972, 20, 275-279. (In Spanish) [PubMed]

95. Almeida, F.B.; Santos, E.I.; Sposina, G. Triatomíneos da Amazonia III. Acta Amaz. 1973, 3, 43-66. (In Portuguese) [CrossRef]

96. Ghauri, M.S.K. The Indian triatomine genus Linshcosteus (Reduviidae). Syst. Ent. 1976, 1, 183-187. [CrossRef]

97. Carcavallo, R.U.; Barreto, P. Una nueva especie de Rhodnius Stål (Hemiptera, Reduviidae, Triatominae) de Colombia. Bol. Dir. Mal. San. Amb. 1976, 16, 176-183. (In Spanish)

98. Martínez, A.; Carcavallo, R.U. Un nuevo Triatominae neotropical (Hemiptera: Reduviidae). Fol. Ent. Mex. 1977, 38, 109-118. (In Spanish)

99. Sherlock, I.A.; Guitton, N.; Miles, M. Rhodnius paraensis espécie nova do Estado do Pará, Brasil (Hemiptera, Reduviidae, Triatominae). Acta Amaz. 1977, 7, 71-74. (In Portuguese) [CrossRef]

100. Else, J.G.; Cheong, W.H.; Mahadevan, S.; Zárate, L.G. A new species of cave-inhabiting Triatoma (Hemiptera: Reduviidae) from Malaysia. J. Med. Ent. 1977, 14, 367-369. [CrossRef]

101. Lent, H.; Wygodzinsky, P. Revision of the Triatominae (Hemiptera, Reduviidae), and their significance as vectors of Chagas disease. Bull. Am. Mus. Nat. Hist. 1979, 163, 123-520.

102. Serra, R.G.; Atzingen, N.C.B.; Serra, O.P. Nova espécie do gênero Alberprosenia Martínez \& Carcavallo, 1977, do Estado do Pará, Brasil. V Congresso Bras. Par. 1980, 126. (In Portuguese)

103. Martínez, A.; Carcavallo, R.U.; Pelaez, D. Triatoma brailovskyi, nueva especie Triatominae de México. Chagas 1984, 1, 39-42. (In Spanish)

104. Barrett, T.V.; Arias, J.R. A new triatomine host of Trypanosoma cruzi from the Central Amazon of Brasil: Cavernicola lenti n. sp. (Hemiptera, Reduviidae, Triatominae). Memórias do Instituto Oswaldo Cruz 1985, 80, 91-96. [CrossRef]

105. Carcavallo, R.U.; Martínez, A.; Peláez, D. Una nueva especie de Triatoma Laporte, de México. Chagas 1987, 4, 4-5. (In Spanish)

106. Fernandez-Loayza, R. Triatoma matsunoi nueva especie del norte peruano (Hemiptera, Reduviidae, Triatominae). Rev. Per. Ent. 1989, 31, 21-24. (In Spanish)

107. Lent, H.; Jurberg, J.; Galvão, C. Rhodnius stali n. sp., afim de Rhodnius pictipes Stål, 1872. Memórias do Instituto Oswaldo Cruz 1993, 88, 605-614. [CrossRef] 
108. Osuna, E.; Ayala, J.M. Belminus pittieri, nueva especie de Bolboderini (Triatominae: Reduviidae: Heteroptera). Bol. Ent. Venez. 1993, 8, 147-150. (In Spanish)

109. Martínez, A.; Carcavallo, R.U.; Jurberg, J. Triatoma gomeznunezi a new species of Triatomini from Mexico (Hemiptera, Reduviidae, Triatominae). Ent. Vect. 1994, 1, 15-19.

110. Lent, H.; Jurberg, J.; Carcavallo, R.U. Belminus laportei sp. n. da região Amazônica (Hemiptera: Reduviidae: Triatominae). Memórias do Instituto Oswaldo Cruz 1995, 90, 33-39. (In Portuguese) [CrossRef]

111. Frias, D.A.; Henry, A.A.; González, C.R. Mepraia gajardoi: A new species of Triatominae (Hemiptera: Reduviidae) from Chile and its comparison with Mepraia spinolai. Rev. Chil. Hist. Nat. 1998, 71, 177-188.

112. Jurberg, J.; Rocha, D.S.; Lorosa, E.S.; Vinhaes, M.C.; Lent, H. Uma nova espécie de Triatoma do Estado do Rio Grande do Sul, Brasil (Hemiptera, Reduviidae). Entom. Vect. 1998, 5, 295-310. (In Portuguese)

113. Carcavallo, R.U.; Galvão, C.; Lent, H. Triatoma jurbergi sp. n. do norte do estado do Mato Grosso, Brasil (Hemiptera, Reduviidae, Triatominae) com uma atualização das sinonímias e outros táxons. Memórias do Instituto Oswaldo Cruz 1998, 93, 459-464. (In Portuguese) [CrossRef] [PubMed]

114. Aguilar, R.A.; Torres, B.N.; Jímenez, M.C.; Jurberg, J.; Galvão, C.; Carcavallo, R. Triatoma bassolsae sp. n. do México, com uma chave para as espécies do complexo "phyllosoma" (Hemiptera, Reduviidae). Memórias do Instituto Oswaldo Cruz 1999, 94, 353-359. (In Portuguese) [CrossRef] [PubMed]

115. Mejia, J.M.; Galvão, C.; Jurberg, J. Rhodnius colombiensis sp. n. da Colômbia, com quadros comparativos entre estruturas fálicas do gênero Rhodnius Stal, 1859 (Hemiptera, Reduviidae, Triatominae). Ent. Vect. 1999, 6, 601-617. (In Spanish)

116. Carcavallo, R.U.; Jurberg, J. Triatoma baratai sp. n. do estado do Mato Grosso do Sul, Brasil (Hemiptera, Reduviidae, Triatominae). Ent. Vect. 2000, 7, 373-387. (In Portuguese)

117. Valente, V.C.; Valente, S.A.S.; Carcavallo, R.; Rocha, D.S.; Galvão, C.; Jurberg, J. Considerações sobre uma nova espécie do gênero Rhodnius Stål, do estado do Pará, Brasil (Hemiptera, Reduviidae, Triatominae). Ent. Vect. 2001, 8, 65-80. (In Portuguese)

118. Carcavallo, R.U.; Jurberg, J.; Lent, H.; Galvão, C.; Steindel, M.; Pinto, C.J.C. Nova especie do complexo oliveirai (nova denominação para o complexo matogrossensis) Hemiptera, Reduviidae, Triatominae) do estado do Rio Grande do Sul, Brasil. Memórias do Instituto Oswaldo Cruz 2001, 96, 71-79. (In Portuguese) [CrossRef]

119. Galvão, C.; Pattersin, J.S.; Silva, D.R.; Jurberg, J.; Carcavallo, R.; Rajen, K.; Ambrose, D.P.; Miles, M.A. A new species of triatomine from Tamil Nadul, India. Med. Vet. Ent. 2002, 16, 75-82. [CrossRef]

120. Papa, A.R.; Jurberg, J.; Carcavallo, R.U.; Cerqueira, R.L.; Barata, J.M.B. Triatoma sherlocki sp. n. coletada na Bahia, Brasil (Hemiptera, Reduviidae, Triatominae). Ent. Vect. 2002, 9, 133-146. (In Portuguese)

121. Carcavallo, R.U.; Jurberg, J.; Rocha, D.S.; Galvão, C.; Noireau, F.; Lent, H. Triatoma vandae sp. n. do complexo oliveirai encontrada no Estado de Mato Grosso, Brasil (Hemiptera: Reduviidae: Triatominae). Memórias do Instituto Oswaldo Cruz 2002, 97, 649-654. (In Portuguese) [CrossRef]

122. Poinar, G., Jr. Triatoma dominicana sp. n. (Hemiptera: Reduviidae: Triatominae), and Trypanosoma antiquus sp. n. (Stercoraria: Trypanosomatidae), the first fossil evidence of a triatomine-trypanosomatid vector association. Vec. Borne. Zoon. Dis. 2005, 5, 72-81. [CrossRef] [PubMed]

123. Galvão, C.; Angulo, V.M. Belminus corredori, a new species of Bolboderini (Hemiptera: Reduviidae: Triatominae) from Santander, Colombia). Zootaxa 2006, 1241, 61-68.

124. Sandoval, C.M.; Pábon, E.; Jurberg, J.; Galvão, C. Belminus ferroae n. sp. from the Colombian north-east, with a key to the species of the genus (Hemiptera: Reduviiade: Triatominae). Zootaxa 2007, 1443, 55-64. [CrossRef]

125. Bérenger, J.M.; Blanchet, D. A new species of the genus Panstrongylus from French Guiana (Heteroptera; Reduviidae; Triatominae). Memórias do Instituto Oswaldo Cruz 2007, 102, 733-736. [CrossRef]

126. Martinez Avendaño, E.; Chávez Espada, T.; Sossa Gil, D.; Asturizaga, R.A.; Mamani, B.V.; Prieto, P.V. Triatoma boliviana sp. n. (Hemiptera: Reduviidae: Triatominae) de los valles subandinos de La Paz-Bolivia, similar a Triatoma nigromaculata Stal, 1859. Bol. Inst. Invest. Salud. Desar. 2007, 3, 87-90. (In Spanish)

127. Costa, J.; Felix, M. Triatoma juazeirensis sp. nov. from the state of Bahia, Northeastern Brazil (Hemiptera: Reduviidae: Triatominae). Memórias do Instituto Oswaldo Cruz 2007, 102, 87-90. [CrossRef] [PubMed]

128. Ayala, J.M. Una nueva especie de Panstrongylus Berg de Venezuela. (Hemiptera: Reduviidae, Triatominae). Entomotropica 2009, 24, 105-109. (In Spanish)

129. Jurberg, J.; Rocha, D.S.; Galvão, C. Rhodnius zeledoni sp. nov. afim de Rhodnius paraensis Sherlock, Guitton \& Miles, 1977 (Hemiptera, Reduviidae, Triatominae). Biota Neotrop. 2009, 9, 123-128.

130. Poinar, G., Jr. Panstrongylus hispaniolae sp. n. (Hemiptera: Reduviidae: Triatominae), a new fossil triatomine in Dominican amber, with evidence of gut flagellates. Palaeodiversity 2013, 6, 1-8.

131. Gonçalves, T.C.M.; Teves-Neves, S.C.; Santos-Mallet, J.R.; Carbajal-de-la-Fuente, A.L.; Lopes, C.M. Triatoma jatai sp. nov. in the state of Tocantins, Brazil (Hemiptera: Reduviidae: Triatominae). Memórias do Instituto Oswaldo Cruz 2013, 108, 429-437. [CrossRef] [PubMed]

132. Oliveira, J.; Ayala, J.M.; Justi, S.A.; da Rosa, J.A.; Galvão, C. Description of a new species of Nesotriatoma Usinger, 1944 from Cuba and revalidation of synonymy between Nesotriatoma bruneri (Usinger, 1944) and N. flavida (Neiva, 1911) (Hemiptera, Reduviidae, Triatominae). J. Vector. Ecol. 2018, 43, 148-157. [CrossRef] 
133. Poinar, G., Jr. A primitive triatomine bug, Paleotriatoma metaxytaxa gen. et sp. nov. (Hemiptera: Reduviidae: Triatominae), in mid-Cretaceous amber from northern Myanmar. Cret. Res. 2018, 93, 90-97. [CrossRef]

134. Monteiro, F.A.; Weirauch, C.; Felix, M.; Lazoski, C.; Abad-Franch, F. Evolution, Systematics, and Biogeography of the Triatominae, Vectors of Chagas Disease. Adv Parasitol. 2018, 99, 265-344.

135. Castro, M.R.J.; Clément, G.; Monteiro, F.A.; Vieira, C.; Carareto, C.M. Homology-free detection of transposable elements unveils their dynamics in three ecologically distinct Rhodnius species. Genes 2020, 11, 170. [CrossRef]

136. Monteiro, F.A.; Barret, T.V.; Fitzpatrick, S.; Cordon-Rosales, C.; Feliciangeli, D.; Beard, C.B. Molecular phylogeography of the Amazonian Chagas disease vectors Rhodnius prolixus and R. robustus. Mol. Ecol. 2003, 12, 997-1006. [CrossRef]

137. Justi, S.A.; Russo, C.A.M.; Mallet, J.R.S.; Obara, M.T.; Galvão, C. Molecular phylogeny of Triatomini (Hemiptera: Reduviidae: Triatominae). Parasites Vectors 2014, 7, 149. [CrossRef]

138. Justi, S.A.; Galvão, C.; Schrago, C.G. Geological Changes of the Americas and their Influence on the Diversification of the Neotropical Kissing Bugs (Hemiptera: Reduviidae: Triatominae). PLoS Negl. Trop. Dis. 2016, 10, e0004527. [CrossRef]

139. Panzera, Y.; Pita, S.; Ferreiro, M.J.; Ferrandis, I.; Lages, C.; Pérez, R.; Silva, A.E.; Guerra, M.; Panzera, F. High dynamics of rDNA cluster location in kissing bug holocentric chromosomes (Triatominae, Heteroptera). Cytog. Gen. Res. 2012, 138, 56-67. [CrossRef] [PubMed]

140. Nascimento, J.D.; Caneguim, B.H.; Paula, M.C.; Ribeiro, A.R.; Sasso-Cerri, E.; Rosa, J.A. Spermathecae: Morphofunctional features and correlation with fat bodies and trachea in six species of vectors of Chagas disease. Acta Trop. 2019, 197, 105032. [CrossRef]

141. Garcia, B.A.; Powell, J.R. Phylogeny of species of Triatoma (Hemiptera: Reduviidae) based on mitochondrial DNA sequences. J. Med. Entomol. 1998, 35, 232-238. [CrossRef] [PubMed]

142. Hypša, V.; Tietz, D.; Zrzavy, J.; Rego, R.O.; Galvao, C.; Jurberg, J. Phylogeny and biogeography of Triatominae (Hemiptera: Reduviidae): Molecular evidence of a New World origin of the Asiatic clade. Mol. Phylo. Evol. 2002, 23, 447-457. [CrossRef]

143. Lasserre, D.F.; Oliveira, J.; Pinotti, H.; Rosa, J.A. Morphological description of Mepraia spp. females (Hemiptera: Reduviidae, Triatominae). Acta Trop. 2019, 190, 389-394. [CrossRef]

144. Rengifo-Correa, L.; Abad-Franch, F.; Martínez-Hernández, F.; Salazar-Schettino, P.M.; Téllez-Rendón, J.L.; Villalobos, G.; Morrone, J.J. A biogeographic-ecological approach to disentangle reticulate evolution in the Triatoma phyllosoma species group (Heteroptera: Triatominae), vectors of Chagas disease. J. Zoolog. Syst. Evol. Res. 2020, 59, 94-110. [CrossRef]

145. Cesaretto, N.R.; Oliveira, J.; Ravazi, A.; Madeira, F.F.; Reis, Y.V.; Oliveira, A.B.B.; Vicente, R.D.; Cristal, D.C.; Galvão, C.; AzeredoOliveira, M.T.V.; et al. Trends in taxonomy of Triatomini (Hemiptera, Reduviidae, Triatominae): Reproductive compatibility reinforces the synonymization of Meccus Stål, 1859 with Triatoma Laporte, 1832. Parasit Vect. 2021, 14, 340. [CrossRef] [PubMed]

146. International Commission on Zoological Nomenclature. The International Code of Zoological Nomenclature. 1999. Available online: https:/ / www.iczn.org/the-code/the-international-code-of-zoological-nomenclature/the-code-online/ (accessed on 28 October 2021).

147. Pita, S.; Lorite, P.; Nattero, J.; Galvão, C.; Alevi, K.C.C.; Teves, S.C.; Azeredo-Oliveira, M.T.V.; Panzera, F. New arrangements on several species subcomplexes of Triatoma genus based on the chromosomal position of ribosomal genes (Hemiptera-Triatominae). Infect. Genet. Evol. 2016, 43, 225-231. [CrossRef]

148. Alevi, K.C.C.; Oliveira, J.; Azeredo-Oliveira, M.T.V.; Rosa, J.A. Triatoma vitticeps subcomplex (Hemiptera, Reduviidae, Triatominae): A new grouping of Chagas disease vectors from South America. Parasites Vectors 2017, 10, 180. [CrossRef] [PubMed]

149. Mendonça, V.J.; Alevi, K.C.C.; Pinotti, H.; Gurgel-Gonçalves, R.; Pita, S.; Guerra, A.L.; Panzera, F.; Araújo, R.F.; Azeredo-Oliveira, M.T.V.; Rosa, J.A. Revalidation of Triatoma bahiensis Sherlock \& Serafim, 1967 (Hemiptera: Reduviidae) and phylogeny of the T. brasiliensis species complex. Zootaxa 2016, 4107, 239-254.

150. Oliveira, J.; Marcet, P.L.; Takiya, D.M.; Mendonça, V.J.; Belintani, T.; Bargues, M.D.; Mateo, L.; Chagas, V.; Folly-Ramos, E.; Cordeiro-Estrela, P.; et al. Combined phylogenetic and morphometric information to delimitand unify the Triatoma brasiliensis species complex and the Brasiliensis subcomplex. Act. Trop. 2017, 170, 140-148. [CrossRef] [PubMed]

151. Belintani, T.; Oliveira, J.; Pinotti, H.; Silva, L.A.; Alevi, K.C.C.; Galvão, C.; Rosa, J.A. Phylogenetic and phenotypic relationships of the Triatoma sordida subcomplex (Hemiptera: Reduviidae: Triatominae). Acta Trop. 2020, 212, 105679. [CrossRef]

152. Padial, J.M.; Miralles, A.; de la Riva, I.; Vences, M. The integrative future of taxonomy. Front. Zool. 2010, 7, 16. [CrossRef]

153. Dorn, P.L.; Calderon, C.; Melgar, S.; Moguel, B.; Solorzano, E.; Dumonteil, E.; Rodas, A.; Rua, N.; Garnica, R.; Monroy, C. Two distinct Triatoma dimidiata (Latreille, 1811) taxa are found in sympatry in Guatemala and Mexico. PLoS Negl. Trop. Dis. 2009, 3, e393. [CrossRef]

154. Dorn, P.L.; de la Rúa, N.M.; Axen, H.; Smith, N.; Richards, B.R.; Charabati, J.; Suarez, J.; Woods, A.; Pessoa, R.; Monroy, C.; et al. Hypothesis testing clarifies the systematics of the main Central American Chagas disease vector, Triatoma dimidiata (Latreille, 1811), across its geographic range. Infect. Genet. Evol. 2016, 44, 431-443. [CrossRef]

155. Panzera, F.; Hornos, S.; Pereira, J.; Cestau, R.; Canale, D.; Diotaiuti, L.; Dujardin, J.P.; Perez, R. Genetic variability and geographic differentiation among three species of triatomine bugs (Hemiptera-Reduviidae). Am. J. Trop. Med. Hyg. 1997, 57, 732-739. [CrossRef]

156. Panzera, F.; Pita, S.; Nattero, J.; Panzera, Y.; Galvão, C.; Chavez, T.; de Arias, A.R.; Téllez, L.C.; Noireau, F. Cryptic speciation in the Triatoma sordida subcomplex (Hemiptera, Reduviidae) revealed by chromosomal markers. Parasites Vectors 2015, 8, $495-504$. [CrossRef] [PubMed] 
157. Dias, F.B.S.; Jaramillo, N.; Diotaiuti, L. Description and characterization of the melanic morphotype of Rhodnius nasutus Stål, 1859 (Hemiptera: Reduviidae: Triatominae). Rev. Soc. Bras. Med. Trop. 2014, 47, 637-641. [CrossRef]

158. Pita, S.; Panzera, F.; Ferrandis, I.; Galvão, C.; Gómez-Palacio, A.; Panzera, Y. Chromosomal divergence and evolutionary inferences in Rhodniini basead on the chromosomal location of ribosomal genes. Memórias do Instituto Oswaldo Cruz 2013, 108, 376-382. [CrossRef] [PubMed]

159. Mayr, E. Animal Species and Evolution; Harvard University Press: Cambridge, MA, USA, 1963.

160. Mayr, E. Populations, Species, and Evolution; Harvard University Press: Cambridge, MA, USA, 1970.

161. Dobzhansky, T. Genetics of the Evolutionary Process; Columbia University Press: New York, NY, USA, 1970.

162. Calderón-Fernández, G.M.; Juárez, M.P. The cuticular hydrocarbons of the Triatoma sordida species subcomplex (Hemiptera: Reduviidae). Memórias do Instituto Oswaldo Cruz 2013, 108, 778-784. [CrossRef] [PubMed]

163. Nattero, J.; Piccinali, R.M.; Lopes, C.M.; Hernandez, M.L.; Abrahan, L.; Lobbia, P.A.; Rodríguez, C.S.; Carbajal de la Fuente, A.L. Morphometric variability among the species of the Sordida subcomplex (Hemiptera: Reduviidae: Triatominae): Evidence for differentiation across the distribution range of Triatoma sordida. Parasit. Vectors 2017, 10, 412. [CrossRef]

164. Oscherov, E.B.; Damborsky, M.P.; Bar, M.E. Características biológicas de Triatoma sordida (Heteroptera, Reduviidae): Ciclo de vida. Revista de la Sociedad Entomológica Argentina 1998, 57, 13-17. (In Spanish)

165. Souza, J.M.P.; Rodrigues, V.L.C.C.; Rocha e Silva, E.O. Triatoma sordida: Considerações sobre o tempo de vida das formas adultas e sobre a oviposição das fêmeas. Revista de Saúde Pública 1978, 12, 291-296. (In Portuguese) [CrossRef]

166. Pinto, C.F. Fatos curiosos sobre a biologia do Triatoma sordida (Nota prévia). Rev. Soc. Bras. Med. 1949, 6, 305. (In Spanish)

167. Rosa, J.A.; Souza, E.S.; Costa, T.A.; Barbosa, R.R.; Souza, A.J.; Belintani, T.; Nascimento, J.D.; Gil-Santana, H.R.; Oliveira, J. Third record of Rhodnius amazonicus and comparative study with R. pictipes (Hemiptera, Reduviidae, Triatominae). Acta Trop. 2017, 176, 364-372. [CrossRef] [PubMed]

168. Rodrigues, J.M.S.; Rosa, J.A.; Moreira, F.F.F.; Galvão, C. Morphology of the terminal abdominal segments in females of Triatominae (Insecta: Hemiptera: Reduviidae). Acta Trop. 2018, 185, 86-97. [CrossRef]

169. Dale, C.; Almeida, C.E.; Mendonça, V.J.; Oliveira, J.; Rosa, J.A.; Galvão, C.; Costa, J. An updated and illustrated dichotomous key for the Chagas disease vectors of Triatoma brasiliensis species complex and their epidemiologic importance. Zookeys 2018, 805, 33-43. [CrossRef] [PubMed]

170. Osório-Quintero, L.; Ceretti, W.; Vendramini, D.P.; Rosa, J.A.; Oliveira, J.; Obara, M.T.; Barata, J.M.S. Morphological study of the urotergite I process in ten species of the genus Triatoma (Hemiptera, Reduviidae, Triatominae). Acta Trop. 2019, 192, 112-122. [CrossRef]

171. Almeida, M.A.R.C.; Freitas, S.P.C.; Oliveira, L.R.; Lima, N.R.C.; Rangel, E.F.; Santos-Mallet, J. Characterization of the Buccula, Rostrum, Stridulatory Sulcus, Scutellum, and External Female Genitalia of Triatoma carcavalloi (Jurberg, Rocha \& Lent, 1998), Triatoma circummaculata (Stål, 1859), and Triatoma rubrovaria (Blanchard, 1843) (Hemiptera, Reduviidae, Triatominae). J. Parasitol. Res. 2019, 2019, 3517098.

172. Oliveira, J.; Almeida, C.E.; Mendonça, V.J.; Alevi, K.C.C.; Costa, J.; Rosa, J.A. Triatoma brasiliensis species complex: Characterization of the external female genitalia. J. Vector Ecol. 2020, 45, 57-68. [CrossRef] [PubMed]

173. Gurgel-Gonçalves, R.; Komp, E.; Campbell, L.P.; Khalighifar, A.; Mellenbruch, J.; Mendonça, V.J.; Owens, H.L.; Felix, K.C.; Peterson, A.T.; Ramsey, J.M. Automated identifcation of insect vectors of Chagas disease in Brazil and Mexico: The Virtual Vector Lab. PeerJ 2017, 5, e3040. [CrossRef]

174. Khalighifar, A.; Komp, E.; Ramsey, J.M.; Gurgel-Gonçalves, R.; Peterson, A.T. Deep learning algorithms improve automated identifcation of Chagas disease vectors. J. Med. Entomol. 2019, 56, 1404-1410. [CrossRef] [PubMed]

175. Actis, A.S.; Traversa, O.C.; Carcavalho, R.U. Estudios taxonómicos sobre el genero Triatoma Laporte mediante la electrophoresis de la linfa. An. Esc. Nac. Cienc. Biol. 1964, 3, 97-106. (In Spanish)

176. Dujardin, J.P.; Chávez, T.; Moreno, J.M.; Machane, M.; Noireau, F.; Schofield, C.J. Comparison of isoenzyme electrophoresis and morphometric analysis for phylogenetic reconstruction of the Rhodniini (Hemiptera: Reduviidae: Triatominae). J. Med. Entomol. 1999, 36, 653-659. [CrossRef] [PubMed]

177. Costa, J.; Freitas-Sibajev, M.G.R.; Marchon-Silva, V.; Pires, M.Q.; Pacheco, R.S. Isoenzymes detect variation in populations of Triatoma brasiliensis (Hemiptera, Reduviidae, Triatominae). Memórias do Instituto Oswaldo Cruz 1997, 92, 459-464. [CrossRef]

178. Flores, A.; Magallón-Gastélum, E.; Bosseno, M.F.; Ordóñez, R.; Lozano-Kasten, F.; Espinoza, B.; Ramsey, J.; Breniére, S.F. Isoenzyme variability of five principal triatomine vector species of Chagas disease in Mexico. Infect. Genet. Evol. 2001, 1, 21-28. [CrossRef]

179. Ueshima, N. Cytotaxonomy of The Triatominae (Reduviidae: Hemiptera). Chromosoma 1966, 18, 97-122. [CrossRef]

180. Alevi, K.C.C.; Mendonça, P.P.; Pereira, N.P.; Rosa, J.A.; Azeredo-Oliveira, M.T.V. Karyotype of Triatoma melanocephala Neiva and Pinto (1923). Does this species fit in the Brasiliensis subcomplex? Infect. Genet. Evol. 2012, 12, 1652-1653. [CrossRef]

181. Alevi, K.C.C.; Borsatto, K.C.; Moreira, F.F.F.; Jurberg, J.; Azeredo-Oliveira, M.T.V. Karyosystematics of Triatoma rubrofasciata (De Geer, 1773) (Hemiptera: Reduviidae: Triatominae). Zootaxa 2015, 3994, 433-438. [CrossRef] [PubMed]

182. Alevi, K.C.C.; Borsatto, K.C.; Moreira, F.F.F.; Jurberg, J.; Azeredo-Oliveira, M.T.V. Karyosystematic and karyotype evolution of Panstrongylus lutzi (Neiva \& Pinto, 1923) (Hemiptera, Triatominae). Braz. J. Biol. 2017, 78, 180-182. [PubMed]

183. Alevi, K.C.C.; Oliveira, J.; Rosa, J.A.; Azeredo-Oliveira, M.T.V. Karyotype Evolution of Chagas Disease Vectors (Hemiptera, Triatominae). Am. J. Trop. Med. Hyg. 2018, 99, 87-89. [CrossRef] 
184. Panzera, F.; Pérez, R.; Panzera, Y.; Ferrandis, I.; Ferreiro, M.J.; Calleros, L. Cytogenetics and Genome Evolution in the Subfamily Triatominae (Hemiptera, Reduviidae). Cytogen. Gen. Res. 2010, 128, 77-87.

185. Imperador, C.H.L.; Moreira, F.F.F.; Rosa, J.A.; Azeredo-Oliveira, M.T.V.; Alevi, K.C.C. Cytotaxonomy of the Maculata subcomplex (Hemiptera, Triatominae). Braz. J. Biol. 2017, 77, 887-889. [CrossRef] [PubMed]

186. Bardella, V.B.; Pita, S.; Vanzela, A.L.L.; Galvão, C.; Panzera, F. Heterochromatin base pair composition and diversification in holocentric chromosomes of kissing bugs (Hemiptera, Reduviidae). Memórias do Instituto Oswaldo Cruz 2016, 111, 614-662. [CrossRef]

187. Alevi, K.C.C.; Bittinelli, I.F.; Delgado, L.M.G.; Madeira, F.F.; Oliveira, J.; Lilioso, M.; Folly-Ramos, E.; Rosa, J.A.; Azeredo-Oliveira, M.T.V. Molecular cytotaxonomy of the Triatoma brasiliensis species subcomplex (Hemiptera, Triatominae). Acta Trop. 2020, 201, 105225. [CrossRef]

188. Ravazi, A.; Oliveira, J.; Campos, F.F.; Madeira, F.F.; Reis, Y.V.; Oliveira, A.B.B.; Azeredo-Oliveira, M.T.V.; Rosa, J.A.; Galvão, C.; Alevi, K.C.C. Trends in evolution of the Rhodniini tribe (Hemiptera, Triatominae): Experimental crosses between Psammolestes tertius Lent \& Jurberg, 1965 and P. coreodes Bergroth, 1911 and analysis of the reproductive isolating mechanisms. Parasites Vectors 2021, 14, 350 .

189. Pita, S.; Lorite, P.; Cuadrado, A.; Panzera, Y.; Oliveira, J.; Alevi, K.C.C.; Rosa, J.A.; Freitas, S.P.C.; Gómez-Palacio, A.; Solari, A.; et al. High chromosomal mobility of ribosomal clusters in holocentric chromosomes of Triatominae, vectors of Chagas disease (Hemiptera-Reduviidae). Med. Vet. Entomol. 2021. In press. [CrossRef] [PubMed]

190. Borsatto, K.C.; Azeredo-Oliveira, M.T.V.; Alevi, K.C.C. Identification Key for the Chagas Disease Vectors of Five Brazilian States, Based on Cytogenetic Data. Am. J. Trop. Med. Hyg. 2019, 100, 303-305. [CrossRef]

191. Borsatto, K.C.; Reis, Y.V.; Garcia, A.C.C.; Sousa, P.S.; Azeredo-Oliveira, M.T.V.; Alevi, K.C.C. CytoKey: Identification Key for the Chagas Disease Vectors of the Largest Brazilian Urban Center (São Paulo State), Based on Cytogenetic Data. Am. J. Trop. Med. Hyg. 2019, 101, 113-115. [CrossRef]

192. Oliveira, J.; Rosa, J.A.; Alevi, K.C.C. Chagas Disease Vectors of Espírito Santo, Brazil: First Report of Triatoma infestans (Klug, 1834) (Hemiptera, Triatominae) in the Brazilian State and Development of an Identification Key Based on Cytogenetic Data. Am. J. Trop. Med. Hyg. 2021, 104, 653-655. [CrossRef]

193. Gonzalez-Britz, N.E.G.; Alevi, K.C.C.; Garcia, A.C.; Martínez-Purroy, C.E.; Galvão, C.; Carrasco, H.J. Chagas disease vectors of Paraguay: Entomoepidemiological aspects of Triatoma sordida (Stål, 1859) and development of an identification key for Paraguayan triatomines based on cytogenetics data. Am. J. Trop Med. Hyg. 2021, 105, 130-133. [CrossRef]

194. Laroche, M.; Bérenger, J.M.; Gazelle, G.; Blanchet, D.; Raoult, D.; Parola, P. MALDI-TOF MS protein profiling for the rapid identification of Chagas disease triatomine vectors and application to the triatomine fauna of French Guiana. Parasitology 2018, 145, 665-675. [CrossRef] [PubMed]

195. Souza, E.S.; Fernandes, R.P.; Guedes, W.N.; Santos, F.N.; Eberlin, M.N.; Lopes, N.P.; Padovani, V.D.; Rosa, J.A. Rhodnius spp. are differentiated based on the peptide/protein profile by matrix-assisted laser desorption/ionization mass spectrometry and chemometric tools. Anal. Bioanal. Chem. 2020, 412, 1431-1439. [CrossRef] [PubMed]

196. Souza, É.S.; Fernandes, R.P.; Galvão, C.; Paiva, V.F.; Rosa, J.A. Distinguishing two species of Cavernicola (Hemiptera, Reduviidae, Triatominae) with matrix-assisted laser desorption ionization time-of-flight mass spectrometry. Acta Trop. $2019,98,105071$. [CrossRef] [PubMed]

197. Carvalho, D.B.; Congrains, C.; Chahad-Ehlers, S.; Pinotti, H.; De Brito, R.A.; Da Rosa, J.A. Differential transcriptome analysis supports Rhodnius montenegrensis and Rhodnius robustus (Hemiptera, Reduviidae, Triatominae) as distinct species. PLoS ONE 2017, 12, e0174997. [CrossRef]

198. Brito, R.N.; Geraldo, J.A.; Monteiro, F.A.; Lazoski, C.; Souza, R.C.M.; Abad-Franch, F. Transcriptome-based molecular systematics: Rhodnius montenegrensis (Triatominae) and its position within the Rhodnius prolixus-Rhodnius robustus cryptic-species complex. Parasit. Vectors 2019, 12, 305. [CrossRef] 